\title{
El atlas invisible. Historias de archivo en torno a la muestra "Almas Robadas - Postales de Indios" (Buenos Aires, 2010)
}

The Invisible Atlas. Archives stories about the "Almas Robadas- Postales de Indios" (Stolen Souls - Postcards of Indians)

\section{Carlos Masotta}

\section{(Q) OpenEdition}

\section{Journals}

Electronic version

URL: http://journals.openedition.org/corpusarchivos/963

DOI: $10.4000 /$ corpusarchivos.963

ISSN: 1853-8037

Publisher

Diego Escolar

\section{Electronic reference}

Carlos Masotta, «El atlas invisible. Historias de archivo en torno a la muestra "Almas Robadas -

Postales de Indios" (Buenos Aires, 2010) », Corpus [En línea], Vol 1, No 1 | 2011, Publicado el 30 junio

2011, consultado el 01 mayo 2019. URL : http://journals.openedition.org/corpusarchivos/963 ; DOI : 10.4000/corpusarchivos.963

This text was automatically generated on 1 May 2019.

Licencia Creative Commons: Atribución-NoComercial 2.5 Argentina (CC BY-NC 2.5 AR) 


\section{El atlas invisible. Historias de archivo en torno a la muestra "Almas Robadas - Postales de Indios" (Buenos Aires, 2010)}

The Invisible Atlas. Archives stories about the "Almas Robadas- Postales de Indios" (Stolen Souls - Postcards of Indians)

Carlos Masotta

\section{EDITOR'S NOTE}

Recibido 02/03/2011

Aceptado 25/04/2011

\section{1. “¿Son de su agrado estas postales?”}

1 Hacia principios de 2009 di por finalizada una investigación a la que dediqué aproximadamente 10 años. El trabajo me había conducido por los pasillos de diversos archivos públicos y privados en búsqueda de viejas postales que inundaron el mundo por primera vez en las primeras décadas del siglo XX. Había comenzado por un interés en la fotografía de indígenas en la Argentina, una práctica que suponía, contaba con la suficiente densidad como para constituirse en objeto de investigación para un antropólogo. No pude reunir un corpus de fotografías representativo pero, en cambio, me encontré con cientos de tarjetas postales que reproducían muchas de las fotos de indios que no se habían preservado en los archivos públicos por diferentes motivos.

2 Escribí artículos, recibí una beca, luego un premio por una monografía sobre el tema, y finalmente, como una reunión de todo eso realicé el libro: “Álbum Postal”. Creí entonces 
llegar al fin de este recorrido. Tal vez, parte de la certeza de haber concluido con la labor se encontraba en que ese libro, de alguna manera, es un archivo. El archivo que no había encontrado al comenzar mi investigación: indígenas, gauchos, paisajes, ciudades, políticos y personas públicas, alegorías del Centenario, diseños humorísticos, figuras románticas. Unas 800 imágenes del universo infinito que formaron las postales argentinas de esa época. Y, más o menos en ese orden, había observado cómo las imágenes de los indígenas se relacionaban con un universo que parecía volver ahora inagotable la fuente documental originalmente escasa y en el que, sin saberlo en un principio, me habían embarcado.

3 Pero en 2010 el tema volvió a convocarme. En los primeros meses de ese año el Fondo Nacional de las Artes aprobó un subsidio para la realización de una muestra sobre postales de indios en el Instituto Nacional de Antropología y Pensamiento Latinoamericano. Habíamos presentado el proyecto de la muestra un par de años antes junto con el personal del Museo del Hombre dependiente de la misma institución ${ }^{1}$. Coincidentemente, se presentó la oportunidad de sumar a la muestra parte de la colección de postales de indígenas que el antropólogo alemán Roberto Lehmann-Nitsche había publicado en la Argentina entre 1902 y 1904. Gracias a una beca del servicio cultural DAAD y la buena disposición del Instituto Ibero-Americano de Berlín, en el mes de julio, me encontré frente a frente con los documentos fotográficos que se conservan en esa institución. Yo, que creía que con "Álbum Postal" había podido salir del archivo de las postales, me encontraba ahora en la distante Berlín, nuevamente, con cientos de postales y fotos de indios que habían sido reunidas en Buenos Aires hacía poco más de un siglo.

4 Conocía las postales que Lehmann-Nitsche había publicado con fotografías propias de su viaje a Tierra del Fuego (1902) y, en particular, la estupenda colección de más de 100 tarjetas que organizara con las fotografías del italiano Gino Boggiani. Pero en realidad, no les había prestado especial atención. Había centrado mi interés en el fenómeno masivo y popular de las postales, y aquellas tarjetas se enrolaban en la academia y en la experiencia de aquel antropólogo en el Museo de La Plata. Además, hasta la consulta en el Instituto Ibero-Americano, no había tenido oportunidad de ver la colección completa.

5 La realización de la muestra "Almas Robadas" y el contacto directo con la colección de Lehmann-Nitsche me hizo volver a reflexionar sobre el caso. En relación con el Instituto Nacional de Antropología y Pensamiento Latinoamericano, donde se montaría la exposición, las tarjetas del antropólogo alemán adquirían nuevo valor, pues, a través de aquel investigador, la antropología argentina se había sumado a la fiebre postal del Novecientos.

6 A continuación describiré algunas imágenes que integraron "Almas Robadas" en la perspectiva de sus historias de archivo. Por esta expresión debe entenderse una forma de adjetivación del devenir de los documentos antes que el pasado de las instituciones o lugares de guarda. Tomo el término de la historiadora Antoinette Burton (2006) quien, a su vez lo inscribe en la tradición del Mal de archivo/archivo del mal de Derrida.

7 Para la fotografía histórica y en especial para la que fuera aplicada a los pueblos indígenas, la perspectiva es apta pues esos documentos no son solo representaciones visuales de personas sino una parte constitutiva de un discurso a la vez universalista, clasificatorio y racializador formado por imágenes que fueron concebidas asimismo para ser organizadas y archivadas en función de ese orden. En resumen, por Historias de archivo debe entenderse no solo las alternativas de la vida documental en el seno de las instituciones de guarda, sino también sus anteriores usos y hasta su propia creación. La 
fotografía fue concebida para documentar el mundo y en eso ya hay una operación de archivo. En definitiva, las historias de archivo no son aquí la historia de las instituciones de guarda sino una forma de abordar al documento mismo como dato, al lugar del documento, su producción, su guarda, su conservación, sus marcas de uso o su destrucción. El documento siempre tiene un archivo y suele intercambiar y hasta confundirse con él. Nótese que la palabra suele usarse tanto para mencionar el lugar de guarda como a la masa documental. El archivo es un constructo político cultural depositario de las formas e intereses involucrados en los ordenamientos que la modernidad ha desarrollado sobre sí misma. Y este principio está inscrito en la misma naturaleza de los documentos que lo habitan. En las últimas décadas, el archivo ha dejado de ser solo una herramienta del historiador para constituirse en un objeto a la vez que en un concepto de interés general para filósofos e historiadores (Foucault 1969, Farge 1991, Derrida 1995, Steedman 2002), para antropólogos (Stoler 2009) e incluso para los estudiosos del campo artístico (Spieker 2008). Las historias de archivo, adoptando estos presupuestos, conducen por las prácticas que involucran a los documentos mientras ellos cambian de lugar y de sentido, se constituyen como tales o abandonan esa condición. En resumen, se trata del devenir del documento, un aspecto especialmente apto para el abordaje de la fotografía histórica.

Esta misma investigación había comenzado con una de estas historias. Como ya comenté, al poco tiempo de andar en busca de un corpus representativo de fotos de indios, encontré que en los principales archivos públicos estas fotografías eran escasas para ese fin. La fototeca del Archivo General de la Nación pareció ser el caso más sintomático. En su apartado "aborígenes" encontré muchas de las imágenes que ya conocía por diversas publicaciones pero que en su dispersión temática y falta de datos complementarios hacia infructuosa la tarea de re-construir sus biografías. Aunque mi interés no se centraba específicamente en la fotografía de antropólogos, los archivos vinculados a esta disciplina podrían haber sido una solución. Sin embargo, en aquel momento, hacia finales de la década de 1990, las consultas en el Museo de la Plata daban pocos resultados pues sus fondos fotográficos, además de estar dispersos en diferentes áreas de la institución, no estaban sistematizados para el acceso público. Por su parte, en la biblioteca del Museo Etnográfico de la Universidad de Buenos Aires comenzaban a organizarse para la preservación de un banco de antiguas fotografías etnográficas en las que recientemente se había reparado.

9 Impulsada por la fotografía antropométrica, en las primeras décadas del siglo XX, la Antropología había fotografiado sistemáticamente a indios, y sus archivos avanzaron en la guarda y clasificación de esos documentos. Pero hacia mediados de siglo y con el cambio y la diversificación de especializaciones disciplinarias, esas fototecas fueron abandonadas. Solo en las dos últimas décadas estos archivos antropológicos comenzaron a ser rescatados a partir de una nueva sensibilidad sobre el documento fotográfico y una lectura crítica sobre sus anteriores usos científicos. También entonces, consulté con resultados similares algunos archivos de las provincias de Buenos Aires, Santa Fe y Chaco: ramilletes de fotos, historias de pérdidas e inundaciones de sótanos.

La carencia o presencia problemática de estos documentos fotográficos en los archivos públicos me hizo reparar en las postales. Aparecían mezcladas entre las colecciones y en un principio, las descarté como un documento de valor inferior por su rústica impresión. Sin embargo, rápidamente noté que ellas crecían en número y que pronto formaban un corpus más representativo que las fotos tradicionales que originalmente buscaba. 
Consultando los álbumes de coleccionistas amateurs, constaté que entre 1900 y 1940 las postales que reproducían fotos de indios habían sido editadas de a miles, y esto cambiaba radicalmente el problema original de la investigación ${ }^{2}$.

11 El problema se me presentaba con dos caras. Una miraba hacia la vida social de esas imágenes en un país que contaba con pueblos indígenas y también con una temprana y amplia divulgación de la fotografía. La otra cara se volvía hacia los archivos, interrogándolos sobre sus colecciones, sus principios de clasificación y de conservación. Ambas señalaban que la fotografía de indígenas en la Argentina se detenía en la aporía de su difusión pública. En efecto, esa fotografía había sido una práctica frecuente desde finales del siglo XIX, pero su paso al archivo parecía no haberse efectuado en forma acorde. ¿Cuál era la naturaleza de ese documento que aunque producido incluso por política de Estado, solo se hallaba hoy disperso y fragmentado? ¿Cuál fue entonces su objeto? ¿Qué tipos de intereses movían al blanco a la posesión de fotos de indios? Entre el exotismo y la ciencia, esas imágenes habían comenzaron a pasar a los indígenas por el fino tamiz de los discursos de la nacionalidad.

Las fotos de indios fueron sin duda numerosas, pero luego de las expediciones, de las campañas militares y los sueños eugenésicos de la antropología física, parecía que no habían encontrado un estante adecuado donde acumularse y preservarse definitivamente. Si en algún momento eso sucedió, posteriormente esos estantes dejaron su lugar a otros documentos. Además las postales de indios con sus escrituras de puño, sus estampillas y números de serie editoriales indicaban que ellas provenían de otros archivos, los del consumo masivo y la vida privada.

Hacia 1900, la reproducción técnica de imágenes al conjugarse, en esos cartones, con la práctica epistolar, logró un proceso de diseminación mundial de iconografía que involucró, en una forma inédita, tanto a sectores burgueses como populares. De todas formas, en los archivos citados encontré solo algunas postales que me indicaron la magnitud del fenómeno en cuestión y me condujeron a archivos privados y a coleccionistas amateurs donde encontré finalmente interesantes corpus iconográficos. Más aun, algunos coleccionistas se habían dedicado específicamente a las postales de indios. Eran las postales las que ahora indicaban la escasez relativa de las fotos pero, al mismo tiempo, señalaban que estas habían logrado nueva encarnadura y que su acumulación y guarda era un fenómeno en sí mismo que había tomado diferentes caminos hasta la actualidad.

14 Las postales de indios no fueron las más numerosas. El negocio fue impulsado por imágenes kitsch dedicadas a niños regordetes, flores, jóvenes pálidas, parejas de enamorados, paisajes turísticos y alegorías de año nuevo. El gusto por las imágenes de salvajes no aparecía del todo claro en el mundo feminizado del intercambio epistolar burgués. En diferentes postales de indios he visto que se repite la nota manuscrita de quien la envió: “¿Son de su agrado estas postales?”. Sin embargo, fueron frecuentes y ocuparon un lugar con límites precisos durante las primeras décadas del siglo XX. Junto a las tarjetas ilustradas con fotos de gauchos, se encargaron de poner en circulación imágenes de los habitantes típicos de la Argentina. En efecto, la postal desarrolló el discurso de nacionalidad en boga brindando una versión iconográfica del país: paisajes de su territorio y retratos de sus pobladores nativos. Así, en aquel mar cálido e indiferenciado de imágenes sensuales ingresó una corriente de tibio nacionalismo que contaba con imágenes propias ancladas con un epígrafe contundente: "República Argentina". Se trataba de las postales nacionales, que hoy pueden verse como un ejercicio 
singular de lo que Benedict Anderson llamó capitalismo de imprenta, en relación a la difusión de un sentimiento de comunidad nacional (Anderson 1993).

\section{2. “Fotografía de Yaneuenque Morales que aún vive con todo vigor"}

Este es el título de la "narración" con que la maestra Juana Romero de la ciudad de Bahía Blanca contribuyó con la "Encuesta nacional de folklore", que en el año 1921 Ricardo Rojas organizara desde el Ministerio de Educación. En relación con el tópico de la muestra "Almas robadas - Postales de indios" encontré ese relato especialmente aleccionador y lo adopté como clave de interpretación general exponiéndolo en la sala de ingreso a la exposición.

En un pequeño pueblo de la Patagonia existía una tribu de indios muy poco civilizada. Un día se presentó un blanco llamado Serafín Basualdo a la choza de Yaneuenque Morales, que así se llamaba el dueño. Serafín le pidió se hiciese fotografiar ya que él tenía la máquina, Morales se negó varias veces a lo que más tarde accedió debido a la insistencia del blanco. Sacada la instantánea, Serafín obsequió con una a Yaneuenque, éste volvió a negarse a tomarla, el blanco salió de la choza dejando la postal sobre un cajón sin que Morales lo advirtiera. Cuando el indio vio la fotografía se desesperó y se la llevó a Serafín entregándosela toda ajada. Le dijo que la arrugó de esa forma para evitar la muerte de él y de su familia. Entre esos indios, la fotografía era presunto de muerte.

En una primera lectura, el texto parece un relato de exotismo que se desarrolla por medio de la típica alteridad primitivismo/tecnología moderna.

Las décadas anteriores habían sido prolíficas en esa figura alegórica del progreso. Recuerdo una postal editada para el Centenario que mostraba a un indígena espantado por un tren que lo encandilaba acercándose a toda marcha. En el mismo sentido, un caso emblemático para la época del relato puede verse en la escena del film "Nanook, el esquimal" (1922) en el que Nanook, después de mostrar la vida tradicional de su pueblo, es enfrentado a un gramófono. El esquimal se asombra, se ríe y termina por oler y morder el disco (¿un gesto caníbal?). Recuérdese el logo que acompañaba al slogan "His master's voice". Lo primitivo y lo tecnológico se construyeron mutuamente y la fotografía de indios fue un producto de ese juego.

La misma "Encuesta nacional de folklore", parecía tener algo de ese espíritu exotista cuando solicitaba a las maestras de escuela la trascripción de la oralidad popular. Pero en "Fotografía de Yaneuenque..." hay más que eso. En la "narración", el indio no se limita a demostrar espanto o extrañamiento ante la fotografía, desarrolla una acción de impugnación, un contra-don. No hay desconocimiento ante la fotografía, sino creencia y acción. La interpretación del avance de la fotografía metropolitana sobre el cuerpo indígena como un anuncio de muerte, ¿no es acaso, un develamiento certero de la creencia blanca en ese fin irreversible? "Fotografía de Yanqueuenque Morales que aún 
vive con todo vigor" trata de una foto y de la supervivencia de Yaneuenque que, rompiéndola, supo rebatir sus oscuros designios.

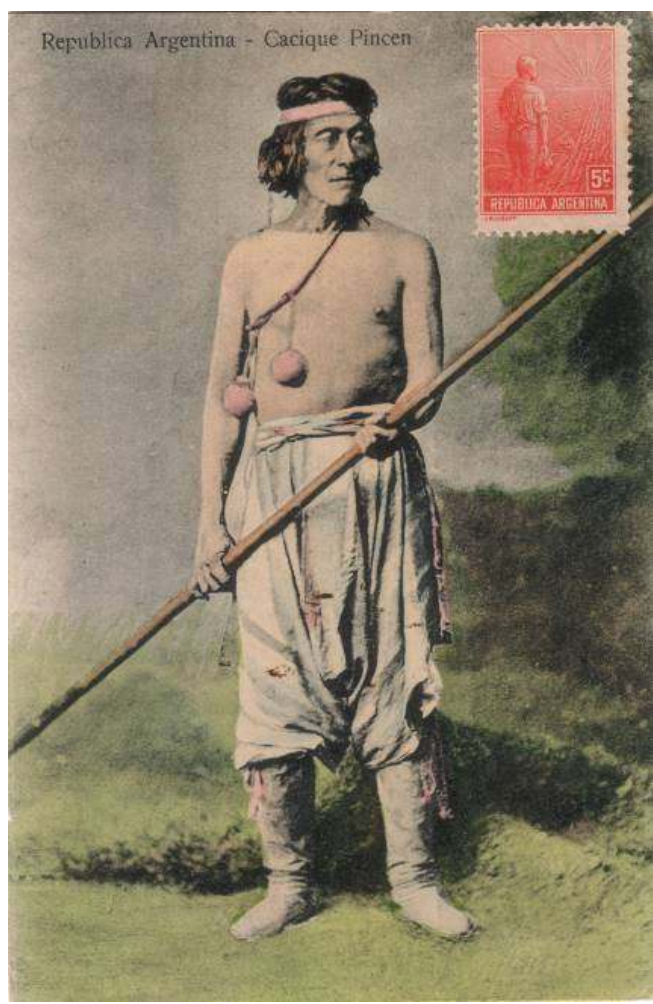

Imagen № 2: Postal "República Argentina - Cacique Pincen". Edición Fumagalli (Ca. 1910) (Colección INAPL)

Finalmente, el relato habla de una fotografía que demuestra no poseer valor de uso en su circuito, sino para el fotógrafo Serafín. Este último, no se contenta con sacar la foto y la ingresa en la casa del indio a pesar de su explícita negativa. Yaneuenque, por su parte, deshace ese camino devolviéndole las fotos arrugadas.

Como puede verse, la historia de archivo que da comienzo a "Almas robadas" es, en realidad, una historia de contra-archivo. De impugnación del documento. Como reza el aforismo benjaminiano, todo documento de cultura es documento de barbarie y este principio sobrevoló nuestra muestra, pues las postales de indios de las primeras décadas del siglo XX, ahora, reenviaban directamente al problema de una ética documental.

\section{El "Cacique Pincen" y las boleadoras rosadas}

Las postales nacionales (de gauchos, de indios y de paisajes argentinos) fueron exitosas en el clima del Centenario y tuvieron incluso editores especializados. Roberto Rosauer fue el más sistemático y conocido. Para 1902 sus avisos declaraban: "Editor de tarjetas postales con vistas de la República Argentina. Precio: \$1 la docena.-\$5: 100 diferentes". En la misma época, Aquilino Fernández también anunciaba la venta de este tipo de tarjetas y competía anunciando "la colección más completa de todas las publicadas hasta la fecha". Aclaraba además: "están en circulación las series de Córdoba, compuesta por 60 vistas; Paraná, 28 vistas; Rosario, 42 vistas;... Chivilcoy, 20 vistas. Próximamente aparecerán otras". 
23 Para las postales de indios, los editores recurrieron a dos tipos de fuentes. En ese momento en Argentina se reconocía la existencia de aproximadamente 15 pueblos indígenas y los editores encargaban tomas a fotógrafos profesionales o estos mismos acercaban a las editoriales sus obras. Pero, además, se recurrió a fotos tomadas en décadas anteriores. Por ejemplo, una foto del cacique Pincén de 1878 circuló, renovada en los primeros años del siglo XX, en forma de tarjeta postal. Las alternativas de esa foto fueron narradas por la prensa de la época y son elocuentes para conocer las peripecias de esa imagen y algunas de sus implicancias (Penhos 1995, 2005). En la muestra "Almas robadas" dedicamos un lugar especial a la postal de Pincén. En la historia de esa imagen se condensan elementos que impulsaron su posterior circulación como postal.

El día 14 de diciembre de 1878, Pincén y los suyos fueron conducidos hasta la fotografía, que se hallaba en la calle Victoria, esquina San José. En un carruaje iban Pincén, Pozzo, un soldado y un indio herido; en un carro, las esposas e hijas del cacique y, a pie, los indios prisioneros. Custodiábanles soldados del Seis de línea. Pincén fue retratado sobre una roca vestido a la moda gaucha, con chiripá, poncho y botas. Una segunda fotografía lo mostraba al lado de cuatro de sus hijas. La tercera placa se destinó a tres de sus mujeres y a sus ocho hijas, y la cuarta a un grupo de indios. Entre los presentes se hallaba don Francisco P. Moreno, quien conocía la lengua araucana. Habló a Pincén en su idioma y mantuvieron un animado diálogo. Pidióle Moreno que se retratara tal como había sido siempre cuando conducía a sus lanceros en el desierto, y el cacique no se hizo repetir la invitación. Arrojó prontamente el poncho y el chiripá, sacóse las botas y adoptó una actitud de fuerza. Trajéronle una lanza, y ante ella, los ojos le brillaron y dilatáronse sus fosas nasales. La tomó con un brusco ademán esgrimiéndola violentamente (en Galíndez 1968: 59).

Image 2000000900002FD5000023912B4B91B6.wmf

Imagen No 3: "Almas Robadas - Postales de indios". Derecha: Vitrina con original y ampliación de la postal "República Argentina - Cacique Pincen" (Co-lección INAPL). Izquierda: ampliación de postal "Republica Argentina- Chaco- Un cacique". Abajo: grupo de postales que repiten la misma imagen con diferentes intervenciones de color e impresión; al centro "Gran Chaco, Republica Argentina - Joven Toba" (Colección del autor).

Como puede verse en la crónica que transcribimos, por "fotografía" se comprendía tanto el objeto que todos conocemos al mismo estudio donde aquel se producía. Reuniendo ambos sentidos, me gustaría señalar a la fotografía como un lugar de enunciación.

Pero tratándose de fotos de indios tomadas por blancos para consumo de estos últimos, ¿quiénes son, en verdad, los que allí se enuncian? A juzgar por la serie de fotografías que se tomaron ese día, no parecen haber sido los ojos del prisionero Pincén los que brillaron, sino los de Francisco Moreno, Antonio Pozzo y su comitiva. Un año después este último, como fotógrafo oficial de Julio Argentino Roca, se encargaría de la confección de un lujoso álbum con vistas de la avanzada militar conocida como "Conquista del Desierto". Así, los indios ya no ingresarían a la fotografía sino que esta se desplazaría hacia su encuentro, en el mismo desierto.

La forma retrato recrea la imagen del sujeto a través de atributos particulares como la vestimenta, la escenografía, el gesto y la pose. Si nos atenemos a la crónica, la toma original en el estudio no consistió en una performance motivada por el deseo de re-crear alguna escena nacional. Se afirma que Pincén cambió su vestimenta gaucha. Sin embargo, la foto difiere en ese punto con la crónica. El cacique muestra su torso desnudo pero mantiene el chiripá y las botas. Además se le han colgado sobre el pecho un par de boleadoras. "Indio gaucho", según uno de sus seudónimos, Pincén ingresó en el mismo acto, en la iconografía fotográfica y, cautivo, a la vida de Buenos Aires. El general Roca, 
Ministro de Guerra, había apurado su traslado a la ciudad. Su fotografía fue un paso más en un cuidadoso plan de exposición pública.

El 11 de noviembre, Conrado Villegas le informó a Roca la captura de Pincén junto con familiares y algunos de sus lanceros y agregando la siguiente aclaración: "Es conveniente dejar a Pincen por unos días en este campamento pues a su vista se han de presentar algunos (indios)" (el destacado es mío).

Desde Buenos Aires, Roca le contestó inmediatamente, imponiendo otra prioridad para la exposición del cacique.

Grande impresión ha causado en ésta [ciudad] la toma de Pincén, el cacique más temido de la Pampa. [...] Pero es necesario que no demore a Pincén y lo mande con todos los tomados. Causará novedad su entrada en esta capital (Olascoaga 1974:15).

Días después de la sesión de fotografías, Pincén fue confinado con otros prisioneros en la Isla Martín García. Pero si Roca quiso obtener algún rédito político con su exposición pública, el saldo parece haber sido relativo. Luis Franco (1967) afirma que al partir hacia su cárcel, la muchedumbre allí reunida no saludó al Ministro de Guerra sino al propio cacique, quien fue "aplaudido con largo brío" (p. 101).

Con Pincén y hasta mediados de la década de 1880 se abrió la serie de fotografías de caciques que, pactando o derrotados, fueron ingresados a Buenos Aires como prisioneros: Namuncurá, Orkeke, Sayhueque, Foyel, Inacayal, entre otros. Con ninguno de ellos se efectuó la operación de exotismo que se dio con Pincén en el estudio de Antonio Pozzo. Tal vez por esto, cuando hacia 1900 la empresa postal revisó la iconografía indígena ya existente, solo reparó en aquella foto del cacique portando lanza y boleadoras. Las imágenes de los otros no fueron ingresadas al nuevo universo que impusieron esas tarjetas.

31 En esa época estaba en pleno auge y se diversificaba el fenómeno criollista que, entre sectores medios y populares, fue muy afecto a los héroes desterrados y perseguidos por la ley (Juan Moreira, Hormiga Negra, El tigre del Quequén, entre otros). La popularidad de Pincén y su relación con el criollismo merece un estudio más pormenorizado.

Desde poco antes del 1900, las postales nacionales hicieron ingresar a los indios en la escena nacional. Y ese fue un pasaje controlado, entre otras operaciones, por los epígrafes y el color. La postal de Pincén es un ejemplo de esa transformación. Es una de las únicas que incluye la identificación del nombre y del rango. En la mayoría, los sujetos no fueron identificados sino como miembros de un colectivo aborigen ("tobas", "tehuelches", "chorotes", "onas", entre otros). Sus boleadoras y la vincha fueron pintadas de color rosa y su chiripá blanco fue intervenido con líneas celestes. El formato estandarizado por la postal (11 centímetros por 9) homogenizaba cualquier diversidad iconográfica que el naturalismo de la fotografía pudiera haber provocado. La postal se constituía en un género comunicacional donde el discurso de la nacionalidad encontró un lecho cómodo. El indígena aparecía allí, luego de las principales campañas militares en su contra, como un buen salvaje y una carta de diferenciación en un proceso de identificación. Un gesto metropolitano y colonial de la nación que afirmaba la posesión de un sujeto exótico sin confundirse con él, pero al mismo tiempo, presentado como rasgo típico. Esta compleja tarea se desarrolló por medio de un régimen de visibilidad controlado. Por ejemplo, en una postal de indios coloreada de la misma época puede observarse la práctica de ese régimen de visibilidad en forma elocuente. En el borde de la postal "Gran Chaco, Republica Argentina - Joven Toba" alguien escribió: "Encarecidamente no muestre esta postal a los españoles por que se van a creer de que somos...”. Antes de enviarla a España, 
trazó su firma y la fecha sobre la imagen. El humor de la frase y el trazo manuscrito coinciden en la operación de ambiguación de una lectura ver-no ver. En primer lugar, la divulgación de la imagen con la indicación "no muestre esta postal", pero también el uso del trazo como tachadura. Puede verse cómo "Encarecidamente no" fue escrito prolijamente sobre las letras del epígrafe de la tarjeta, donde la palabra "Toba" es intervenida por "no", al igual que el trazo de la firma marca el rostro de la "joven". Finalmente, los exagerados puntos suspensivos, muestran y ocultan algo que, como un secreto a voces, todos saben pero no puede decirse en público.

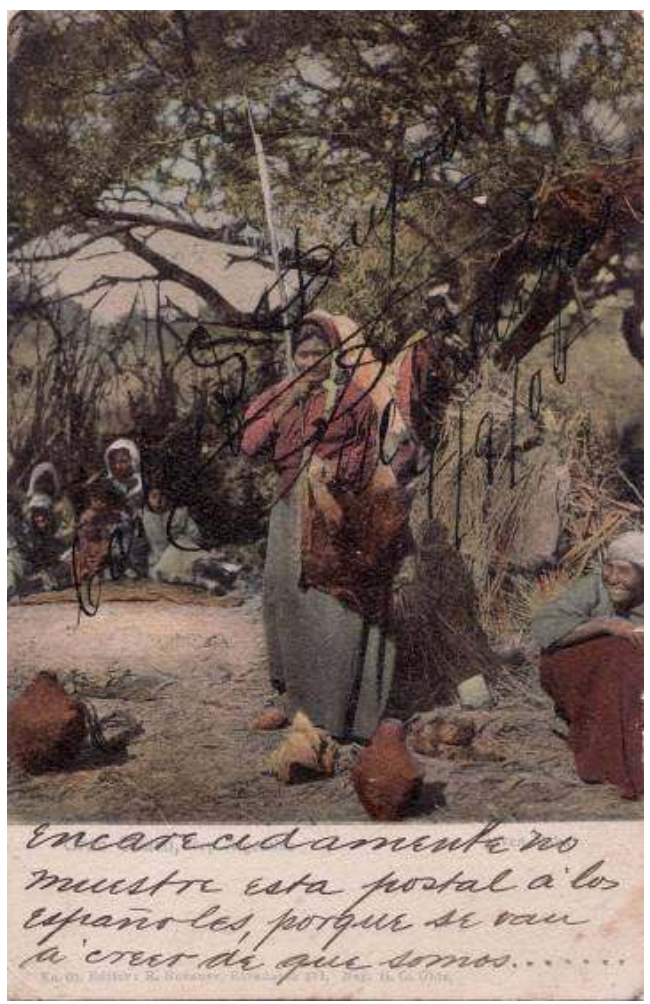

Imagen N 4: "Gran Chaco, República Argentina - Joven Toba" (Colección del autor)

Las postales acuareladas fueron las primeras fotos en colores de consumo masivo y su impacto debió ser importante pues se difundieron con asiduidad. Con los colores, las imágenes ganaban en atractivo y realismo pero también con ellos se desarrollaban la imaginación involucrada en los intercambios epistolares y el control del género comunicacional en los márgenes de la cortesía, la cordialidad y el humor. Si en la foto original de Pincén, con la lanza y las boleadoras se quiso mostrar la bravura del cacique, ahora, con los colores de su postal, la imagen del prisionero se incorporó en el nuevo mundo de la colección privada y del lenguaje amoroso que comenzaba a compartir con sus pares dentro de los gruesos álbumes con decoraciones art nouveau de consumo frecuente entre sectores medios y altos. Las postales feminizaron los cuerpos indígenas aplicando tópicos ya desarrollados por el orientalismo en la pintura europea. Con todo, la imagen de Pincén, el "indio gaucho", pudo ser asimismo una breve interjección del criollismo en ese lenguaje estereotipado que desarrollaron las postales nacionales. Ninguna otra postal mostraría a un cacique en pose de pelea. Las pocas que insistieron con la mención de ese rango lo hicieron señalando al mismo tiempo que ya no se contaba con esa autoridad. Puede compararse la imagen de Pincén con la postal "Republica Argentina- Chaco- Un cacique", como un ejemplo en ese sentido. 


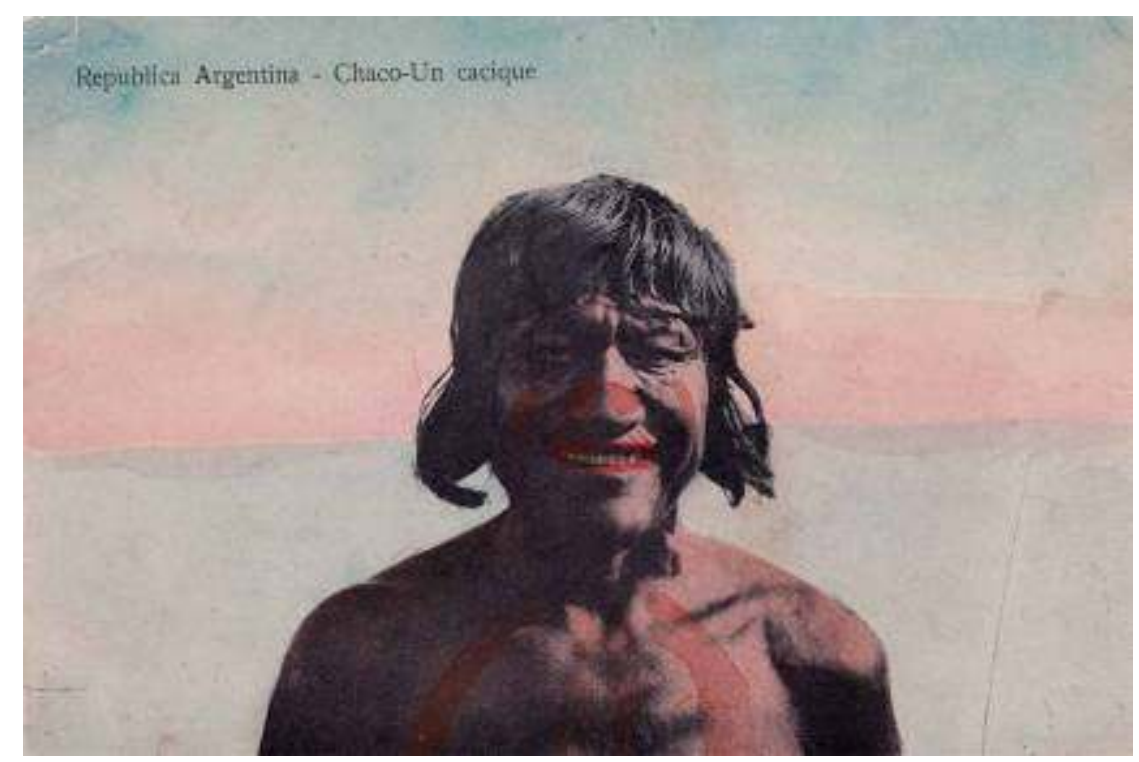

Imagen No 5: "Republica Argentina - Chaco - Un cacique" (Colección del autor). fotográficos pertenecientes al antropólogo Roberto Lehmann-Nitsche, encontré entre ellos una copia en albúmina del retrato de Pincén. Allí, a miles de kilómetros de Buenos Aires, la imagen del viejo cacique mostraba otros aspectos de su encrucijada. La foto tenía las marcas de una nueva autoría. No llevaba el sello del fotógrafo Antonio Pozzo, sino el de "S. Rimathe. Fotografía Buenos Aires - 442". Esto muestra que esa fotografía circulaba entre fotógrafos y se difundía con cierta asiduidad. Su numeración y copia en albúmina indican que había sido clasifica-da e integrada a una serie antes de su pasaje a la postal y que ese retrato despertaba interés también para la Antropología.

Lehmann-Nitsche había llegado a la Argentina en 1897 contratado por el Museo de Ciencias Naturales de La Plata. Tres años después, tal vez se haya sentido atraído por el anuncio con que Samuel Rimathe cerraba, para entonces, su negocio en Buenos Aires: "Por liquidación: gran surtido de vistas del país, a precios reducidos" (Cunietti-Fernando 1996). Retrospectivamente, la foto de Pincén no podía faltar en la colección de quien, cultor por igual del criollismo y la antropología física, se propuso relevar a la propia cultura argentina ${ }^{3}$.

\section{La "tribu invisible" y las postales de Roberto Lehmann-Nitsche}

En 1899 Roberto Lehmann-Nitsche envió al pintor y etnógrafo Guido Boggiani, que se hallaba en Paraguay, su trabajo "Quelques observations nouvelles sur les indies Guayaquí du Paraguay", recientemente publicado en los Anales del Museo de La Plata. Boggiani le respondió sobre ese escrito con el siguiente comentario:

Mucho y en especial modo me interesa..., y es posible que escriba algo sobre ciertas noticias que Ud. expone en él. Acabo de volver de una exploración por territorios habitados por esa tribu invisible, y el contenido de su folleto me servirá de mucho en mis investigaciones.

En su carta, Boggiani, subrayó la palabra "invisible". En los últimos años, él se había constituido en uno de los principales etnógrafos del Chaco para-guayo aplicando la 
fotografía con especial fascinación. Mezcla de intelectual dandi, artista y comerciante, había sumado la fotografía a su destreza para el dibujo y la pintura en el registro de los pueblos indígenas de la región. El intercambio epistolar entre los dos hombres muestra la articulación singular de dos fuentes diferentes de la escritura etnográfica de la época: la formación en Ciencias Naturales y la Patología en el caso de Lehmann-Nitsche, y en arte, en el de Boggiani. La retórica visual que comparten la "tribu invisible" y "Quelques observations" sugiere una motivación común por la mirada de lo indígena, a la vez que anticipa los acontecimientos que involucrarán a ambos investigadores en torno a ese tópico.

Dos años después de ese intercambio, Boggiani no regresó de una de sus expediciones. En 1902 un grupo de rescate encontró su cuerpo decapitado junto a su máquina de fotos. Según la versión más divulgada, los responsables habrían sido miembros del pueblo chamacoco, uno de los grupos indígenas a quienes Boggiani más había fotografiado. Dos años después Lehmann-Nitsche publicó una colección de postales que reprodujo más de 100 fotografías del desafortunado italiano.

Mirar lo indígena implicaba al mismo tiempo exponerlo, describirlo, mostrarlo y mostrarse a través de esa acción. La relación entre ver-ser visto, la tensión entre el voyeur y el exhibicionista descansa, en la fotografía etnográfica, sobre una tercera figura que es el mismo cuerpo indígena exhibido, se encarna en él. Esta tercera figura, luego de ver y ser visto, consiste en un hacer ver al otro, donde están involucradas secretamente las dos primeras. La recurrencia y sistematicidad que adoptará la fotografía de indígenas en ese período puede considerarse como el resultado de una peculiar pulsión escópica intercultural desarrollada por diversos ejercicios de exotismo visual (fotografías, pinturas, postales, ex-posiciones internacionales, museos) $)^{4}$.

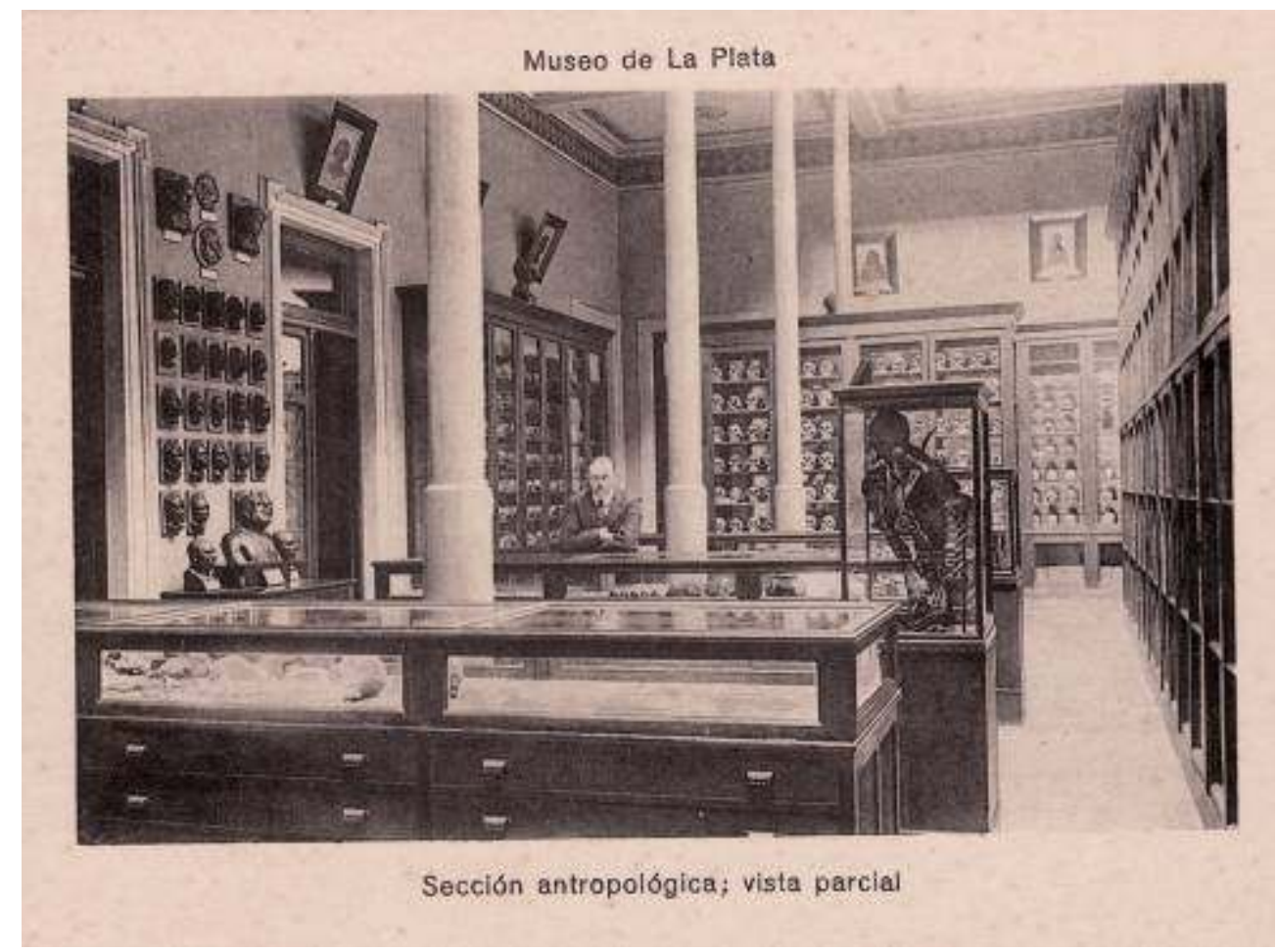

Imagen No 6: Postal "Museo de la Plata - Sección Antropología: vista parcial" (Colección Instituto Ibero-Americano). 
40

erto Lehmann-Nitsche (1872-1938) desarrolló en la Argentina una de las experiencias de investigación más singulares que haya producido la historia de la Antropología local. Residió en este país desde 1897 hasta 1930 desempeñándose como responsable de la sección de Antropología del Museo de la Plata. Desde ese lugar, realizó algunos viajes de investigación por el interior del país y produjo numerosos trabajos de antropología física sobre diferentes grupos indígenas. Había sido contratado para ello por su formación académica. Asimismo, demostró pronto interés por aspectos culturales de esas poblaciones, como sus lenguas, el pasado arqueológico o sus mitos. Practicó, con igual o, tal vez, mayor fervor, investigaciones sobre lo que en sus textos aparece como "el alma popular", "Folklore nacional" o "Folklore Argentino". Un área con límites difusos, pero que se centraba en la figura pintoresca del gaucho, de su historia, sus usos, costumbres, literatura y música que lo involucraban. Para 1900, en las principales ciudades argentinas como Buenos Aires, Rosario o La Plata, detrás de esa imagen se desarrollaba un proceso político-cultural donde se debatían las transformaciones sociales del país con una activa y novedosa participación de sectores populares y letrados: el criollismo ${ }^{5}$.

41 La colección de fotografías y postales del antropólogo que se han conservado en Berlín suman aproximadamente 3000 piezas y en ellas puede notarse ese tránsito permanente entre el interés por el indio del interior del país y por el gaucho de las ciudades. Este último, adoptaba el carácter de mito, recreado por miles de publicaciones callejeras, disfraces de carnaval, representaciones teatrales y cantores populares. Los indios, por su parte, se debatían en el ingreso compulsivo al capitalismo, su despojo territorial y el confinamiento en misiones religiosas. A pesar de lo distante de ambas situaciones, el criollismo desarrollaba algunas conexiones y los indígenas ingresaron, aunque subordinadamente, al universo de esa escena popular y nacional en gestación ante el advenimiento cercano del centenario patrio (1910). Como ya dijimos, en las primeras décadas del siglo XX, se imprimieron por igual series de indios y de gauchos. Ambos eran presentados como los habitantes autóctonos del país, aunque nunca en copresentes en la misma imagen ${ }^{3}$.

En su inmensa mayoría, las fotos reunidas por Lehmann-Nitsche son de estos dos tipos nacionales. Por su exhaustividad y sistematicidad puede observarse el carácter taxonómico y coleccionista de la labor del antropólogo. Se trataba de los procedimientos que la Antropología de la época aplicaba, a veces con tal determinación, que la colección pareció constituirse en un fin en sí mismo. No es extraño el estrecho vínculo de la Antropología de la época con los museos de ciencias naturales y etnográficos (clasificación, guarda, exhibición).

43 Para entonces, el Museo de la Plata editó una serie de postales que publicitaban a la institución. En una de ellas, puede verse a Lehmann-Nitsche al frente de la sala de la Sección Antropología. Es la única de la serie que muestra a un funcionario del Museo; el resto consiste en imágenes de piezas etnográficas o paleontológicas, vis-tas del edificio y algunas de sus salas. Por su afección a las postales, tal vez, haya sido él mismo quien gestionó su edición. Su cuerpo, apoyado sobre una vitrina y rodeado de colecciones de cráneos indígenas, posa la colección. Es decir, muestra que el individuo está involucrado en ella y que, como un moderno Atlas, sostiene con la custodia de su saber ese universo. Pero la figura de ese mito se ha invertido. Ya no es el universo el que descansa sobre sus hombros sino a la inversa. Este sujeto descansa en ella, se muestra en ella, se enuncia en la colección y en el museo. 

2004) y en los últimos años se produjeron tesis doctorales en torno a ese corpus y otros asociados (Yujnovsky 2010, Martínez 2011). Por lo general, se las ha descripto sucintamente, reconstruyéndose los pasos de su producción y circulación: las expediciones de Boggiani en Paraguay hasta su trágica muerte (1901); la adquisición de las fotos por la Sociedad Argentina de Fotógrafos Aficionados y el editor Rosauer en Argentina y la publicación final organizada por Lehmann-Nitsche. E incluso, un litigio por derechos de propiedad sobre las fotos entablado por un albaceas de Boggiani en contra, también, del Museo de La Plata. Finalmente, nuevas ediciones de esas postales, coloreadas y sin sus marcas originales de autoría, que circula-ron por lo menos hasta 1940. Agregaré un dato más. La "Colección" lleva el sello editorial "Buenos Aires 1904 - Casa Editora R. Rosauer". Pero las tarjetas fueron impresas en Alemania por Alphons Adolph, renombrado imprentero y fotógrafo conocido por haber sido uno de los primeros inventores de la tarjeta postal fotográfica (Leclerc 1986). En el legado del antropólogo se encuentra la correspondencia entre ambos sobre la edición de Rosauer.

Como se ve, los caminos de la "Colección" fueron muchos y la persistencia en su circulación (antropólogos, museos, fotógrafos, imprenteros, editores, consumido-res anónimos) puede adoptarse como un índice de que, más que una simple reunión de fotos de indios, fue un hecho social. ¿Cuál era la peculiaridad de esas tarjetas que hacían de su publicación una acción a la vez accidentada e inevitable? ¿Cuál era, en definitiva, la pulsión escópica que sustentaba su producción y persistencia? Como ya lo sugirió el clásico texto de Durkheim y Mauss (1998) las formas de clasificación deben ser sometidas a análisis sociológico y la "Colección" aparece entonces como expresión de un discurso clasificatorio que, en su ejercicio, vinculaba al campo académico con el consumo popular.

En relación a estos interrogantes avanzaré sobre dos puntos. En primer lugar, en torno a la relación colección-atlas. Desde ahí podrán observarse algunos aspectos relevantes en el armado y características de esas postales. En segundo lugar, describiré sucintamente un grupo de ellas. 


\title{
4.1. Entre el álbum y el atlas
}

\author{
Lehmann-Nitsche concluía:
}

Con la publicación de sus magníficas fotografías cumplimos con un deseo de nuestro finado amigo que había pensado en la edición de un atlas antropológico, y colocamos la última corona en la tumba del gran artista y etnólogo: GUIDO BOGGIANI. (Lehmann-Nitsche 1904).

Como cultor de la Antropología física en el Museo de La Plata, el mismo Lehmann-Nitsche estaba, desde su llegada a la Argentina, embarcado en la realización de su propio "atlas antropológicos". Eso se consumó sobre todo en "Etudes anthropologiques sur les Indienes Takshik" (1904) y en "Estudios antropológicos sobre los chiriguano, chorote, mataco y toba" (1907/8). Pero también en trabajos más breves como "Relevamiento antropológico de una india Guayaqui" (1908), y otros basados en observaciones realizadas durante sus primeros años en el país pero publicados con posterioridad: "Etudes anthropologiques sur les indies ona" (1905), "Una india yagan" (1916), "Relevamiento Antropológico de dos indias alakaluf" (1916), entre otros. En todos ellos se recurrió a la fotografía antropométrica fundada en los métodos de Alfonso Bertillon y en la identificación de tipos raciales inaugurada por Francis Galton, padres de la criminología y la eugenesia, respectivamente. Con todo, las postales de Boggiani compiladas por Lehmann-Nitsche fueron un híbrido que mezclaba al álbum con el atlas. En esta superposición la noción de colección varía. Mientras en el primero es parcial en el segundo es total. El punto es crucial para la representación visual de la raza y se desarrolla en un proceso que abarca por lo menos los siglos XVIII y XIX. Los trabajos de Lehmann-Nitsche al respecto se ubican en el último escalón de ese recorrido en el cual la fotografía se aplicó de forma sistemática.

51 Tanto Galton como Bertillon habían reparado en el efecto acumulativo y seriado desencadenado por la re-producción técnica de la imagen fotográfica en general.

Mientras en el seno de la vida privada burguesa el álbum compendiaba esas imágenes organizando el relato de vida familiar, la mirada clínica formó sus propios álbumes, ahora con sujetos anónimos que representaban grupos discretos: delincuentes, enfermos y razas. Entre los primeros los más famosos fueron "La identificación antropométrica" (1893) de Bertillon y el "Atlas" de "El Hombre criminal" (1878) de Lombroso. Representantes de los segundos fueron el "Atlas" de "Mecanismo de fisionomía humana" (1862) de Guillaume Duchenne y la "Iconografía fotográfica de la Salpetriere" (1875-1880). Finalmente, con el "Álbum fotográfico de Antropología y Etnología" (1873) realizado por Carl Dammann a pedido de la Sociedad de Antropología de Berlín se mostraba que la raza había entrado decididamente en el mismo dispositivo. El libro reunió más de seiscientas fotografías de sujetos organizadas por continentes en diferentes láminas de 50 por $60 \mathrm{~cm}$ aproximadamente. Las fotos eran de orígenes diversos reunidas por el propio Dammann en viajes y posiblemente en diferentes casas de fotografía alemanas.

Para su "álbum" (aunque en realidad era un atlas) aprovechó el formato carte de visite que se había popularizado mundialmente desde mediados de siglo XIX. Se trató de fotografías de formato pequeño que permitían impresiones repetidas en un solo paso. Las carte de visite se impusieron tanto en los álbumes familiares como en los intercambios

Corpus, Vol 1, No 1 | 2011 
interpersonales de los miembros de las familias burguesas. Rápidamente, a ese uso de exaltación moral del individuo, se sumaron otras aplicaciones tales como el retrato de sujetos coloniales. En efecto, las burguesías incipientes de diferentes partes del mundo no europeo recurrieron a esas imágenes como un moderno consumo exótico vinculado a su propia experiencia local de avance civilizador. Y la Antropología embarcada en el auge del atlas racial encontró que, en forma amateur, la fotografía ya lo había iniciado por medio de la carte de visite. En América tuvo especial incidencia en la zona andina de Perú y Bolivia (al respecto ver un exhaustivo trabajo en Poole 2000). En manos de la ciencia, el álbum se constituye en atlas, es decir en un dispositivo de verificación. Pero nótese que el recurso a la carte de visite, no se fundamenta exclusivamente en un registro directo del autor sino también en la recopilación de imágenes ya diseñadas. Un acto de recopilación y ordenamiento fotográfico que operó en paralelo al registro directo del cuerpo racial. La recopilación y el intercambio de foto-grafías de sujetos y territorios coloniales fue una tarea común a los antropólogos de esa época. La autoridad del saber antropológico fundada en la experiencia directa se institucionalizará luego de las primeras décadas del siglo XX con la sistematización del "trabajo de campo" (Clifford 1995).

El "atlas" es un dispositivo que actúa por acumulación de imágenes organizadas como las partes de un universo particular: territorio, especie animal o vegetal, cuerpo humano $u$ otro. Fundado en los principios de exposición y exhaustividad, el atlas hace visible ese universo constatando su irrefutable existencia. La autonomía relativa que las imágenes poseen en él les confiere un mayor poder de producción de verosimilitud que en un libro ilustrado. En el atlas, las imágenes son manipulables e intercambiables pues su orden se encuentra, en verdad, fuera del texto. Es decir, en la creencia de la existencia del mismo universo descrito que es presentada como emanado de él mismo. El atlas la confirma, es uno de sus efectos. Opera como un efecto de esa realidad. Permite ver el mundo con la verdad de la ciencia. Se trata también de un efecto de archivo, pues su resumen de golpe de vista presupone una acumulación sistemática que lo sustenta. El atlas detiene el flujo del mundo que ahora será inspeccionado desde sus láminas antes que a la inversa. Esta actitud, se representa en la Lección de anatomía (1632) de Rembrandt, donde los observadores de la disección no miran el cadáver sino el texto abierto que se ha dispuesto a los pies del cuerpo (Barker 1984) ${ }^{6}$. Se atribuye ese libro a la obra de Vesalio, el primer atlas moderno del cuerpo humano. Unas décadas antes de aquel cuadro, en 1595, se había inaugurado el término "atlas" para una compilación de mapas de Mercator (Crone 1998).

Image 2000000900002FD500004510854F3A94.wmf

Imagen $N^{\circ} 7$ : Vitrina que describe los usos de fotografía de fueguinos en las postales y textos académicos de Roberto Lehmann-Nitsche. Muestra "Almas Robadas - Postales de Indios".

55 Los orígenes cartográficos del "atlas" en el siglo XVI y su pronta adopción por la Anatomía y luego por la Historia Natural, muestran los rápidos intercambios entre la colonización europea del mundo y la difusión de las técnicas y formas de describirlo y clasificarlo, desde el territorio hasta el cuerpo humano.

El arte del retrato de raza se incorporó al atlas con los presupuestos taxonómicos de la Historia Natural que, avanzado el siglo XVIII comenzó a ver con los ojos de los exploradores europeos y del colonialismo. La Historia Natural había ubicado a la vista en el centro de su empresa clasificatoria de la vida, pues dicha taxonomía encontraba en la forma y el color de los especímenes el criterio holístico para su ubicación precisa en un listado (Foucault 1984) y el presupuesto para su textualización. En ese análisis, la perspectiva eurocéntrica de Foucault descuida el lugar que tuvieron las expediciones 
científicas de circunnavegación y la experiencia de los naturalistas en América y otras partes del mundo (Pratt 1997, Poole 2000). El retrato de raza consistente en la figura de un sujeto caracterizado como tipo o modelo realizaba una operación visual sinecdóquica que, sin embargo, en el texto escrito la Historia Natural no llegó a describir con claridad hasta el siglo XIX. Los cuerpos de indígenas americanos fueron dibujados hasta el siglo XVIII con contornos similares al de los europeos. El caso merece una investigación más detenida, pero en una primera aproximación esos retratos parecen haber ingresado a los manuales de Historia Natural de la mano de aquellas exploraciones. Los textos fundacionales (Bufon, Linneo) no avanzaban en detalles visuales exhaustivos sobre las variaciones físicas de los hombres en el mundo, pero para el siglo XIX los retratos de aquellas expediciones comienzan a ilustrar los tratados cada vez con mayor profusión hasta igualarse con los dibujos y grabados de plantas y animales ya presentes en las primeras obras clásicas. En muchos de ellos se repetían o estilizaban los rostros que aparecieron originalmente en textos de viajes como los de las expediciones de Cook (1772-1775) donde con una galería de retratos anónimos se describía a los hombres y mujeres de diferentes puntos del globo más allá de Europa.

Hacia mediados del 1800 Heinrich Berghaus publicó su estupendo Physikalischer Atlas que dedicaba el primer tomo a meteorología y geología, el segundo a la distribución mundial de animales, vegetales y, "razas humanas". Estas eran mostradas en "mapas etnográficos". La lámina dedicada a su ubicación mundial no ahorra en recursos: colores que diferencian territorios según la disposición por raza, gráficos con curvas estimando densidad de población, relación con climas, dibujos de cráneos y rostros de coloreados y formas contrastantes.

Como se ve, en el siglo XIX el "atlas" poseía aptitudes no solo para la Geografía sino también para la Historia Natural, la Antropología e incluso la Historia. Ya se habían publicado los primeros "Atlas históricos". Con una pedagogía del golpe de vista, el atlas actualiza el mito de un soporte de la totalidad del universo. El recurso a la imagen es indispensable pues se ha incorporado un observador ante el cual ese universo desfila lámina por lámina. El atlas ha sintetizado, detenido e invertido la narración viajera del viaje imperial donde se encontraban los primeros pasos de su versión racial. Los retratos raciales fueron una práctica regular de los viajes de circunnavegación del siglo XVIII y las operaciones básicas de recreación fisionómica ya se pueden observar en ellos antes que se desarrollara el registro fotográfico.

Esta última había sofisticado sus métodos, y con ellos se embarcaba hacia finales de ese siglo en la profundización de esa descripción con la certeza de que el proceso de modernización daba por tierra con esa heterogeneidad racial que cubría el mundo según lo mostraba el atlas de Berghaus: en América, los pueblos indígenas estaban condenados a desaparecer en forma inminente $y$, si no se apuraba su relevamiento visual, el atlas racial de esta parte del mundo quedaría incompleto para siempre. Los antropólogos encontraron en la fotografía la tecnología ideal para responder en forma inmediata a ese requerimiento (Edwards 1992, Pinney 1992, Masotta 1995).

Todas las fotos de indios que reunió Lehmann-Nitsche (propias o ajenas), obedecieron a ese plan de rescate y recopilación. Pero aquella pulsión que conducía al atlas racial no era solo un producto de la ciencia sino del desarrollo de la sociedad burguesa y metropolitana. Para la época, ver y mostrar la raza fue un imperativo que se consumó en la exposición de la diferencia cultural a través de la escenificación y la administración del cuerpo indígena. Y en ello, la fotografía científica, naturalista y romántica no se oponía, 
sino que se encontraba sobre un mismo escenario. Los trabajos de Lehmann-Nitsche, sobre "los indios ona" (1905) y sobre "los Takshik" (1904) arriba citados, fueron realizados con sujetos trasladados a Buenos Aires con destino a la "Exposición Nacional de Buenos Aires" (1889) y a la "Exposición Universal de París (1900), respectivamente. El uso de las exposiciones nacionales o universales, para observaciones antropológicas fue frecuente. En 1881 el patólogo Rudolf Vilchow dio una conferencia sobre las medidas antropométricas de un grupo de onas que era exhibido en el zoológico de Berlín. La publicación de esa conferencia incluyó graba-dos de los rostros de los indígenas y su estructura textual fue replicada en los escritos de Lehmann-Nitsche, quien se reconocía su seguidor.

61 Si en esas exposiciones metropolitanas, de alguna manera, la curiosidad pública acercaba los indios a los antropólogos, el camino inverso también fue transitado.

62 Los sujetos fotografiados para "Estudios antropológicos sobre los chiriguano, chorote..." fueron retratados en un ingenio azucarero de Jujuy, donde eran incorporados compulsivamente y en condiciones de servilismo al trabajo de la cosecha de caña. La fotografía de indígenas en esos obrajes fue frecuente ya que el contexto concentracionario de explotación facilitaba el acceso al indígena y su docilidad para el registro. Ese mismo circuito fue utilizado regularmente por los fotógrafos de la empresa postal hasta 1940. Otro ejemplo de la articulación de la fotografía antropológica con el consumo popular de postales se dio en las fotografías de "Una india yagan" (1916) y "Relevamiento Antropológico de dos indias alakaluf" (1916). Estos trabajos fueron producto del viaje de Lehmann-Nitsche a Tierra del Fuego en 1902, pero antes de esas publicaciones las imágenes fueron utilizadas en una serie de postales (Yujnovsky 2010). La imagen correspondiente a la india yagan del primero de esos textos fue recortada de una fotografía que la mostraba sentada junto a otras cuatro mujeres onas. Con este último grupo Lehmann-Nitsche publicó la postal "Indias Onas, Río del Fuego. Tierra del Fuego. Rep. Argentina" mientras que la imagen recortada de la india yagan sería reservada a la publicación académica posterior. Podría decirse que con ese corte, como en el cuadro de Rembrandt, el antropólogo miraba hacia un imaginario atlas racial, antes que a la escena que había encontrado en Tierra del Fuego: las fotografías fueron tomadas en un puesto policial.

La taxonomía racial no acepta el mestizaje, ni la copresencia de sujetos de diferentes grupos étnicos. La búsqueda de la antropología física de un tipo estándar o promedio se articulaba así con la idea de pureza racial. En el caso de la foto recortada para editarse como postal, puede comprenderse el cuidado del antropólogo de ser fiel al imperativo de separación en grupos. Sin embargo, esa fue una característica de la postal de indios en general y la gran mayoría de estas imágenes no fueron hechas por antropólogos. El atlas racial estaba generalizado y representaba a la raza a través de clases o grupos independientemente de si en la foto posaban varios sujetos o uno solo. La concepción del tipo racial hacía posible la magia de unir las características del grupo al individuo y viceversa (Sekula 2003, Poole 2000). La raza se trataba en definitiva de un modelo explicativo, fácil de deslizar-se hacia otras dimensiones sociales: la clase, el territorio, el carácter, el delito, el género, el grupo cultural o étnico (Balibar y Wallerstein 1991, Wieviorka 1992).

Un ejemplo del razonamiento comparativo y totalizador que sustentaba el atlas racial puede encontrarse en los trabajos que Lehmann-Nitsche publicó paralelamente a la "Colección" en el Museo de la Plata. El más acabado de ellos en forma de atlas fue 
"Estudios antropológicos sobre los chiriguanos, chorote, mataco y tobas" (1907/8) que se presentó en una lujosa encuadernación incluyendo un sobre con decenas de planchas sueltas con las fotografías antropométricas. Transcribo a continuación algunos de sus párrafos. Para simplificar el texto he reducido la mención del número de las planchas con fotos por letras aleatorias.

Fisonomía:

La fisonomía presenta, como siempre sucede cuando entramos a estudiar un grupo de individuos de otra raza, cierta semejanza entre individuos de la misma tribu y, por otra parte, bastante variedad individual.

Entre los hombres chiriguanos hay individuos de aspecto robusto y fuerte y otros de contextura delgada y fina; el contraste de este tipo de poeta decadente con el robusto campesino de la misma lámina que luce varios tajos, no deja nada que desear. 

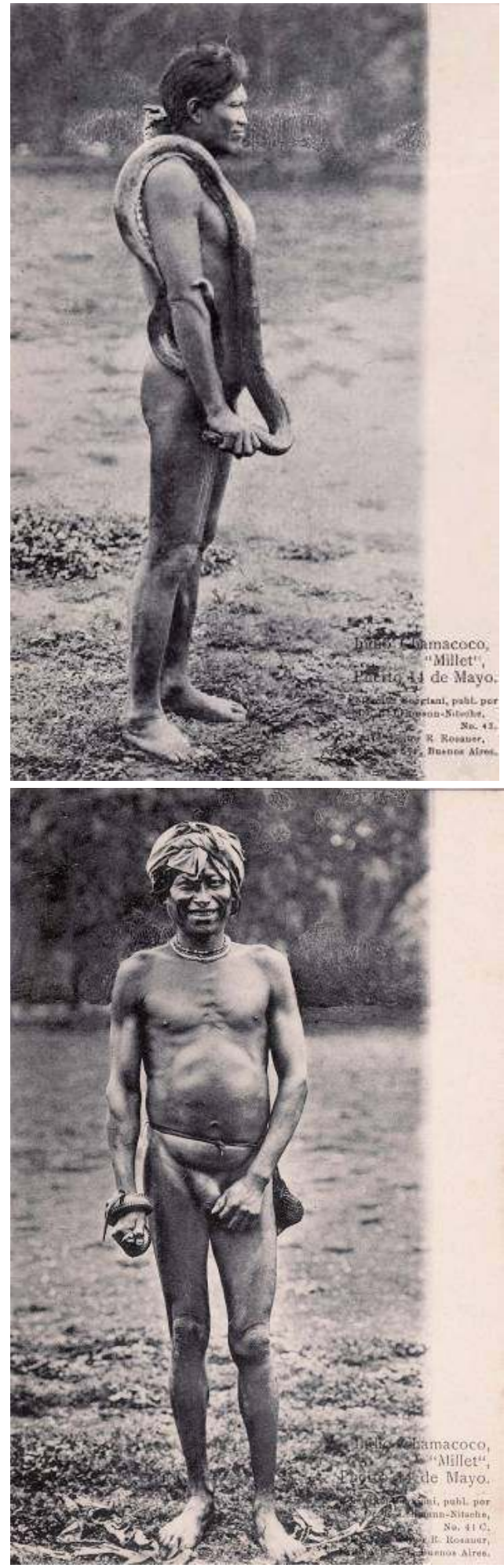

Imagen Nº y N 9: Postales 43 y $41 \mathrm{C}$ de la "Colección de Tipos indígenas". "Indio Chamacoco 'Millet' Puerto 14 de Mayo" (Colección Instituto Ibero-Americano).

Llaman la atención el número de fisonomías hebreas; las hemos reunido en la plancha VI; ante todo el muchacho tiene todos los rasgos característicos del judío. La nariz, los labios, etc. También el joven de la plancha 6 tiene algo de esto. La aparición de fisonomías hebreas en plena América no es un rasgo aislado y fue también observada en otras partes [...] 
Entre los chorote hay tipos verdaderamente primitivos. Los demás individuos no presentan rasgos "americanos" tan marcados. El anciano (X) y el mozo (Y), en algo recuerdan fisonomías Zulu, etc. El hombre (Z) se distingue de sus compañeros y recuerda a los matacos.

Las mujeres chorote son hermosas cuando jóvenes, pero pronto se nota la vanidad de todo bello "ach die rosen welken bald!". La mujer figura 4 muestra todos los rasgos primitivos de la raza americana, cabeza maciza, base de la nariz baja...

Los matacos son bastante diferentes entre sí. Fisonomías muy diferentes primitivas alternan con otras bastante indiferentes (Y), en los hombres no falta la barba, [... ] Las mujeres mataco, no menos sucias y llenas de piojos que los hombres, presentan por lo general, más bien fisonomías diferentes ( $\mathrm{T}$ ) y quedan en parte, bonitas, con los años.

Entre las planchas ( $\mathrm{X}$ e $\mathrm{Y}$ ) he reunido fisonomías que me recuerdan los tipos que bien conozco entre las vende-doras de las calles de Buenos Aires; naturalmente nada tienen que ver en cuanto a consanguinidad con aquellas. Como los tipos hebreos deben considerarse como producto de continuo cruzamiento consanguíneo. En cuanto a las mujeres tobas, no dispongo de suficiente material. Presentan más bien un tipo primitivo que indiferente (Lehmann-Nitsche 1907:64-65).

En este sentido, la raza operaba con la certeza de un atlas invisible que la fotografía develaría en sus mínimos detalles en un futuro no muy lejano. Pero como se sabe, ese futuro llegó en forma de exterminio. Y es posible que la leyenda del "robo del alma" o la fotografía racial como "presunto de muerte" haya sido precisamente un comentario que anticipaba ese destino.

\subsection{La colección y la risa de Millet}

Con las postales de indios, el atlas racial profundizó su ingresó al consumo popular y masivo y "La Colección Boggiani de Tipos indígenas de Sudamérica Central" encontró su lugar en esa encrucijadas de la visión metropolitana de la raza. Un atlas racial de postales, ubicado entre lo público y lo privado, entre la ciencia y el consumo masivo, puede hoy observarse como una cita singular de la fuerza que adquirió la difusión de ese tópico. La raza fue uno de los relatos generalizados y hegemónicos que explicó el mundo entre finales del siglo XIX y principios del XX.

Boggiani no desarrolló trabajos de antropología física y, aunque sus fotografías poseen muchos de sus supuestos, sospechamos que, a pesar de lo sugerido por Lehmann-Nitsche, no estaban originalmente orientadas a un atlas racial tradicional. Los rostros serios, de frente y perfil y los telones de fondo clásicos de la antropometría conviven allí con retratos sonrientes, se reiteran muchos nombres étnicos de los sujetos y poses naturalistas que no eran aceptados por los presupuestos de aquella fotografía científica.

La transformación de esas fotos en la "Colección Boggiani de Tipos..." mantuvo esas marcas originales, pero además las organizó numerando las imágenes y disponiéndolas por grupos lingüísticos y "tribus". Los nombres étnicos fueron rigurosamente antecedidos por la pertenencia aborigen: "Indio chamacoco 'Nepótio'", "india Chamacoco 'Opiét'”, etc. impresos en epígrafes en las tarjetas. La "Colección" fue acompañada de un "Índice" donde se agregaban algunos datos suplementarios. Por ejemplo:

№ 29 Mujer de más de 40 años de pelo crespo y traje negro (viuda). Figura ent. De frente. [...]

№ 39 Hombre de 18 años "Weddi" ("Vicente") con el pecho ensangrentado. Busto de frente. [...]. 
№ 85: Mujer de 20 a 25 años, hermana de "Nepótio"

№ 40-41) esclava entre los indios caduvéo (Mbyá). Río Nabilequé. Busto de frente.

[...]

№ 99: Mujer de 80 a 90 años, con el cabello completamente blanco (rareza entre los Indios), Puerto 14 de mayo. Figura de frente.

El listado permitía componer micro-narraciones internas, pues siguiendo la numeración se establecían vínculos entre individuos o era posible observar a un mismo sujeto en diferentes actitudes. El caso requiere un estudio más pormenorizado. Aquí solo comentaré una de las series internas que pone en relación al corpus principal y público de la "Colección" con su "suplemento reservado", el apéndice de 14 tarjetas de circulación restringida que completaba la edición.

70 Se trata de las 6 postales dedicadas al "Indio chamacoco Millet". En las cinco correspondientes a las tarjetas de circulación pública, el modelo posa de frente y de perfil cargando una gran boa; en otra, de espalda sosteniendo unos pescados y un fusil; la cuarta es un busto de frente y riendo; y luego, de frente, "con sus dos hijos" portando flores, también riendo.

71 En una época en la cual la sonrisa aún no había ingresado decididamente al estereotipo del retrato fotográfico, podría suponerse que la risa de Millet es la expresión ingenua y extrañamiento del contacto primitivo con la escena de toma fotográfica (como la risa de Nanook ante el fonógrafo en la clásica película etnográfica). En esta sexta postal correspondiente al "suplemento reservado", Millet posa de frente y cuerpo entero con una pequeña serpiente apretada en el puño derecho mientras con la otra mano hace lo propio con su pene mientras ríe mirando a la cámara. En el folleto fue descripta simplemente como "Hombre de cuarenta años 'Millet' ", y con su numeración se la asocia, por un lado, a la serie de imágenes de diferentes hombres desnudos del "Suplemento" y por otro, a la serie de fotos de "Millet" del cuerpo principal de la "Colección".

72 La reunión (y a la vez, la separación) consecutiva, en la "Colección", de las tres postales de Millet posando con serpientes obedeció a criterios de observación y compa-ración corporal propios de la Antropología Física a pesar de que el sujeto fotografiado posara con un animal, sin duda, un elemento ajeno a la asepsia de los métodos antropométricos. Con ese conjunto, Lehmann-Nitsche reprodujo también, una secuencia en la que Boggiani centró su objetivo fotográfico en un juego de asociaciones sexuales masculinas entre la serpiente, el cuerpo del indígena, su pene y su risa. La boa que atraviesa el torso de Millet en las tomas de frente $\mathrm{y}$ de perfil concluye sujetada por la cabeza cubriendo cuidadosamente con ese gesto los genitales del modelo. En estas, él posa serio, como una expresión de fuerza sosteniendo al gran animal. Pero en la foto restante ríe (¿obscenamente?) en la pose antes descripta. Las transformaciones entre las imágenes y ese ordenamiento que muestra y oculta la tercera foto se parece al remate de un chiste que fuera insinuado en las anteriores.

73 Las postales de "Millet" son un ejercicio de orientalismo en territorio americano. La serie de imágenes insisten sobre el tópico clásico del encantador de serpientes, e incluso en esa tercera postal frontal la cabeza del indio fue adornada con una especie de turbante.

74 En este sentido es posible establecer un vínculo con la clásica pintura "el encantador de serpientes" (ca. 1860) de Gérôme. Un cuadro clave del discurso y el estereotipo orientalista en términos de una erótica imperial (Nochlin 1991). A pesar del título de la obra, en ella no se muestra simplemente al personaje sino a un anciano musulmán acompañado por un grupo de hombres sentados que observan la performance de un joven 
que sostiene una gran serpiente en torno a su cuerpo desnudo. Como a este "encantador" se lo ve de espaldas y comparte su protagonismo en la escena con su audiencia masculina que lo mira de frente, lo que ellos ven queda así oculto a los ojos del espectador y el cuadro se carga de erotismo y misterio oriental. El joven es ubicado en un centro de observación enfrentado a su audiencia (representada en el cuadro) y secundado por la mirada del espectador del mismo. "El encantador..." puede verse como un ejercicio de estética homoerótica con fantasías pedófilas pero, en el contexto de la pintura orientalista, parece una pieza más en función de la feminización de la cultura de otro.

No habría que descartar dimensiones humorísticas en esa representación que coloca el trasero de un joven en el centro de la escena rodeada de objetos fálicos y a un anciano observando cómo el encantador mantiene en alto a la gran serpiente. En sus trabajos sobre folclore y literatura popular Lehmann-Nitsche prestó especial atención al humor sexual $\mathrm{y}$, posiblemente, él mismo era un cultor del género. El humor parece un terreno aún inexplorado en el campo de las investigaciones sobre fotografía y antropología de la época, sin embargo las fotografías y postales coloniales del periodo crearon un universo exótico, que encontraba su poder de seducción en la confluencia de atracción y rechazo lograda por medio de efectos de erotismo y humorismo que sostenían la ambiguación. Tanto la carte de visite como la fotografía de estudio convencional ya habían incurrido en un género de fotografías que ponía a indígenas en escenas, antes que etnográficas, ridículas. Por ejemplo en Perú se repetían imágenes de "despiojadores" don-de se veía a un indígena andino sacando piojos de la cabeza de otro (Poole 2000), o la foto de cabinet de Gustavo Millet "dentista araucano sacando una muela" (Alvarado, Mege y Báez Allende 2001). El tono frecuente de las escrituras de puño en ese tipo de postales delata ese uso como chanza, una dimensión constitutiva del intercambio epistolar (como en el caso "no muestre esta postal..." comentado más arriba). La fotografía antropométrica descompuso esa operatoria, a pesar de que, como hemos comentado, cohabitó con esas otras imágenes. En una carta, un amigo llama a Lehmann-Nitsche "antropólogo y jodón" (Bilbao 2004Silvia2014-09-10T23:37:00).

Image 2000000900002FD500001C89D7F39EAC.wmf

Imagen $N^{\circ} 10$ : Vitrinas con postales y fotos ampliadas de la colección Lehman-Nitsche (Colección Instituto Ibero-Americano).

IMAgE 2000000900002FD5000023B47A32D99F.WMF

Imagen $\mathrm{N}^{\circ}$ 11: Otra imagen de la muestra (Fotos I. Yujnovsky).

Las postales generaron rápidamente la circulación de un banco iconográfico que, aunque organizado en diversos géneros, se diversificaba a sí mismo con innovaciones constantes y nuevos usos. Fueron incorporadas entre las buenas maneras de relación interpersonal que se enrolaban en anteriores fórmulas del trato burgués. Pero ahora, esas formas se popularizaban con la difusión de la alfabetización. Instantáneamente junto a las postales de uso familiar aparecieron las humorísticas y de contenido erótico. "La Colección de Tipos indígenas..." con su peculiar numeración y clasificación explicativa, parecía intentar controlar algo de ese palimpsesto mundial de imágenes que la edición de postales había generado. Los recaudos no valieron de mucho. Unos años después de la edición original, esas imágenes circularon individualmente, coloreadas y sin el sello de sus gestores. Identificados simplemente como indios del "Chaco", su edición en Argentina los confundía con indígenas de ese, por entonces, "Territorio Nacional", cuando en realidad eran imágenes de sujetos pertenecientes a grupos de la frontera norte del Paraguay. En una de estas tarjetas observé un caso de feminización. Un ejemplar 
coloreado de la postal 47 de "la Colección" correspondiente al "Indio Chamacoco Apulei Pretá" fue enviado en 1907 a París con la nota manuscrita "Femme indígene", a pesar de que se tratara de la imagen de un hombre.

Tal vez todo esto confluyera explicitándose en un uso singular de lo que fue el último capítulo del auge de las postales de indios en la Argentina entre 1930 y 1940: las tarjetas que mostraban a indias completamente desnudas dispuestas en diferentes escenas con poses frontales de pie o sentadas exponiendo su vagina. Todas las fotos fueron tomadas en ingenios azucareros donde esas mujeres eran fuerza de trabajo en la región chaqueña. Todas se editaron anónimamente y circularon con asiduidad con epígrafes como "belleza indígena". He constatado el uso de ese mismo tipo de imágenes en fotografías amateurs de la misma época.

Con todo, el orientalismo fue superado por el atlas racial. En estas fotos se termina con el tropo de misterio. El cuerpo indígena es mostrado desde todos los ángulos. La fotografía se plegó a los presupuestos de un conocimiento total y su ingreso al campo científico la delata como una máquina del positivismo. Al mismo tiempo, su utilización para el registro del cuerpo indígena y la apropiación popular de esa iconografía operó en función de descomponer cualquier atributo de poder que lo indígena pudiera aún poseer. Su cuerpo era observado como aquel atlas en la mesa de disección.

Image 2000000900002FD50000403CC1A4B203.wmf

Imagen $\mathrm{N}^{\circ} 12$ : Otra imagen de la muestra (Fotos I. Yujnovsky).

\section{Comentarios finales}

Recuerdo la fascinación que me provocaba de niño un tipo de imágenes escolares con descripciones de la naturaleza y la historia, que podían mostrar en una sola lámina a "los mamíferos", "los romanos", "los mayas" o "los indios de la Patagonia". En ellas, el listado, la tipología o la numeración habían sido reemplazadas por el escenario donde los miembros de esos grupos se reunían naturalmente, como las estrellas de una constelación o las montañas un mapa físico. El contacto con esas láminas me generaba un placentero efecto de saber y de poder. A esos sujetos se los pescaba in fraganti y tal cual eran, con la certeza de que no obedecían a otro escenógrafo que a ellos mismos y que no percibían la presencia del observador. Uno jugaba a ser el espía de su mundo. Mirando esas láminas se conocía, por ejemplo, en un tigre a todos los tigres.

El impacto que causaban poseía un efecto de Atlas ya aprendido. Es decir, la certeza de que existen los universos finitos y las descripciones totales de ellos: el fundamento mismo de la idea de clasificación.

81 El atlas racial fue anterior a la fotografía. Es decir, ya estaba contenido en los esquemas que la Historia Natural propuso al ubicar al hombre en el mismo mundo que los animales y las plantas. Con la llegada de la fotografía, la Antropología Física o Somática que, como una rama de la Historia Natural se había aplicado al cuerpo humano, creyó encontrar un avance en sus métodos descriptivos y la abrazó con decisión. Sin embargo, sus resultados en ese terreno no fueron más allá de lo que se había logrado antes, más bien tuvieron nuevas aplicaciones. Desde el siglo XIX y, luego de la abolición de la esclavitud, la raza se reformuló como un principio abstracto, liberal, tanto científico y académico como popular. 
82 La Antropología descubrió que la fotografía poseía un poder de representación más minucioso que el dibujo que la precedía, pero también que la raza era una abstracción que operaba por generalización. De hecho, el principio de los tipos raciales de Galton se basaba, no en una foto científica o perfecta, sino en una mancha generada por la superposición de muchas de ellas en la cual se leía el tipo. La fotografía, en su particularismo, mostraba imágenes de sujetos que necesitaban ser operadas discursivamente para conformarlas en tipos raciales. Paradójicamente, en esta imperfección, la fotografía mostraba que la raza era un principio invisible y tanto era así, que para que ésta se expresara había que descomponer las imágenes naturalistas que esa nueva tecnología producía. De alguna forma, la fotografía ponía en apuros al inventario racial, pues parecía mostrar lo infinito del universo a catalogar. Pudo llevar a la clasificación a su extremo más comprometido, que es el de sugerir la arbitrariedad del universo que la sustenta. Algo de esto sucedió con la producción afiebrada de imágenes postales y algunas de las sus aplicaciones por la experiencia surrealista iniciado el siglo XX. Pero por su parte, la fotografía racial endureció sus métodos para ajustarse a los tipos de sus clasificaciones.

Como ha indicado Michael Foucault (1984), es la propia operación de inventario la que mantiene la autonomía del universo. Para el caso, cito como él, la clasificación de animales de la enciclopedia china borgeana:

En sus remotas páginas está escrito que los animales se dividen en (a) pertenecientes al Emperador, (b) embalsamados, (c) amaestrados, (d) lechones, (e) sirenas, (f) fabulosos, (g) perros sueltos, (h) incluidos en esta clasificación, (i) que se agitan como locos, (j) innumerables, (k) dibujados con un pincel finísimo de pelo de camello, (l) etcétera, (m) que acaban de romper el jarrón, (n) que de lejos parecen moscas $^{7}$

Image 2000000900002F4800001D3A6D2F55CC.wmf

Image 2000000900002FD500001DC7D1B684AF.wmf

Imagen $\mathrm{N}^{\circ} 13$ y $\mathrm{N}^{\circ} 14$ : Otras imágenes de la muestra.

Las características de las divisiones propuestas parecen sublevar el orden del universo que describen, pero su organización y enumeración lo controla creando su unicidad.

La Antropología hizo caso omiso del problema que la fotografía acarreaba al atlas racial y respondió a él con la fotografía antropométrica y el archivo de Bertillon. No se trató exclusivamente de un método que manipulaba cuerpos delante del objetivo, sino de una forma de hacer visible la raza por medio de la acumulación y clasificación de imágenes, y enunciar con esa clasificación, sistemas de relaciones históricos, morales y sociales. La comunicación entablada entre los archivos (y los atlas) policiales, hospitalarios y raciales muestra la dimensión a la vez disciplinaria y biopolítica de ese uso de la fotografía. En este sentido, ella surgió como una tecnología obediente a esos mandatos visuales de la Historia Natural del XVIII. La obra de Lehmann-Nitsche es particularmente elocuente de la ubicación generalizada de ese atlas en la sociedad de su época. Así, hasta los retratos risueños de Boggiani pudieron ingresar al corpus científico del investigador y éste a su vez diseminarse con facilidad en el tráfico epistolar de las primeras décadas del siglo XX. Así también, la foto de algunos chiriguanos o matacos según el atlas de Lehman-Nitsche, confirmaban la existencia incuestionable de fisonomías "hebrea", "zulú", "la raza americana", "los rasgos característicos del judío", "el tipo de poeta decadente", por supuesto, los tipos "primitivo" e "indiferente" y "los tipos que bien conozco entre las vendedoras de las calles de Buenos Aires". 
86 En relación al atlas hospitalario de la Iconografía fotográfica de la Salpêtrièr, DidiHuberman (2007) ha comentado el lugar del "vistazo" como acto confirmatorio de la mirada clínica. Ya no acción de ver despreocupada y azarosa sino más bien el golpe de vista que identifica y confirma un saber previo. El atlas es, tal vez, uno de los dispositivos principales del golpe de vista. En el último verano el mismo Didi-Huberman coordinó en el Museo Reina Sofía de Madrid la muestra “ATLAS. ¿Cómo llevar el mundo a cuestas?” donde reunió diferentes obras en torno a esa idea, desde el "Atlas Mnemosyne" (1924-29) del historiador del arte Aby Warburg.

Como se ve, el auge fotográfico del atlas también fue aplicado al arte. Luego fueron los artistas los que hicieron comentarios al respecto. Warburg y Lehman-Nitsche fueron contemporáneos y aunque no sabemos si supieron el uno del otro, el atlas de alguna manera cruzó allí a la Antropología con el Arte. Recordemos que las postales del antropólogo las tomó del artista Boggiani. Esto abre otro problema vinculado tanto a las resistencias al atlas como a la imaginación que el mismo impulsa y a una pregunta sobre la verdadera potencia del golpe de vista y hasta dónde, además de sus certezas, no provee al mismo tiempo interrogantes. Las vanguardias de las primeras décadas del siglo XX fueron, de alguna manera operaciones de contra archivo. Ellas se sumaron al primitivismo y visitaron con frecuencia colecciones etnográficas. Significativamente, en su estadía en la Argentina en 1919, Marcel Duchamp visitó el Museo de la Plata y se entrevistó allí con Lehamnn-Nitsche (Antelo 2006).

El dilema que se presentó al montar la muestra “Almas Robadas. Postales de indios" era si al exponer esas imágenes no reproducíamos la misma lógica, la misma pulsión que las había producido en su origen. Para enfrentar esta encrucijada nos propusimos intervenir ese archivo (ese atlas) con sus propias fotos a través de dos procedimientos generales. En primer lugar presentamos las imágenes como documentos histórica y culturalmente construidos de tal forma que expresen sus historias de archivo presentando los procesos sociales de clasificación en los que se involucraron y así interpelar al público visitante desde los efectos de racismo allí producidos. En segundo lugar, recurrimos a la ampliación de las imágenes originales a una escala que aproximara las dimensiones del cuerpo fotografiado a las del mismo espectador. Como dijimos, estas imágenes fueron originalmente objeto de un proceso de estereotipación, de acumulación y lectura de atlas que imponía la pedagogía del resumen en el golpe de vista. La miniaturización de los cuerpos indígenas en la fotografía fue una pieza clave de esa operatoria. Con la ampliación de esas imágenes se evidenciaron tanto los procedimientos de esterotipación (poses, decorados) e intervención editorial (montajes, trucos, intervención de colores) como expresiones de los rostros, casi invisibles en los tamaños originales. Así se hizo posible percibir claros indicios de la relación desigual entablada entre el fotógrafo con el fotografiado en el instante de la toma, pero que ahora, desde esa foto ampliada se volvía un gesto de interpelación general, pues el espectador frente a la imagen ocupa el mismo ángulo que aquel fotógrafo. Para señalar que la muestra ubicaba su atención en esa relación más que en las fotos en sí mismas, en diferentes lugares incluimos tecnología fotográfica como viejas cámaras y trípodes junto a objetos etnográficos (de las colecciones del $\mathrm{Mu}$-seo del Hombre) similares a los que aparecían en algunas postales. Repusimos textualmente información que orientara la interpretación de casos particulares como la fotografía de indígenas en los ingenios azucareros. Las fotos del archivo de LehmannNitsche cedidas por el Instituto Ibero-Americano de Berlín se distribuyeron en una de las salas. En el centro se ubicaron dos vitrinas especiales con las postales originales de la 
“Colección Boggiani de tipos indígenas". En torno a ellas y sobre las paredes se dispusieron ampliaciones de fotografías de diferentes indígenas. En una vitrina reunimos originales, postales y textos del antropólogo que describían el caso de las postales fueguinas arriba comentadas. En la sala produjimos un doble contraste entre el juego de escala y entre el sujeto y su serialización. héroe mitológico de quien se tomó ese nombre. Como se sabe, Atlas no fue en su origen una recreación cartográfica del universo, sino el esforzado titán que, casi de rodillas, sufriendo la carga, lo sostiene sobre sus hombros. Precisamente, el universo y su inestable soporte. En el uso moderno del atlas, se propició la salida de escena de aquel personaje que fuera reemplazado por una simple representación del mundo. Con el atlas moderno se produjo un corrimiento semántico. En él, el forzudo héroe mitológico fue ocultado por el texto que dibuja el universo que aquél estaba condenado a sostener. La identidad de quien sostiene el mundo se oculta invisibilizando a Atlas, pero ella se delata en el temblor de su inestable equilibrio.

\section{BIBLIOGRAPHY}

Alvarado, M., Mege, P. y Baez Allende, C. (1992). Mapuche. Fotografías Siglo XIX y XX. Santiago: Pehuén.

Anderson, B. (1993). Comunidades imaginadas. México: Fondo de Cultura Económica.

Antelo, R. (2006). María con Marcel. Duchamp en los trópicos. Buenos Aires: SXXI.

Arenas, P. (1989-90). La Antropología del siglo XIX y principios del XX en la Argentina. Runa XIX. $147-175$.

Arenas, P. (1991). Antropología en la Argentina: el aporte de los científicos de habla alemana. Buenos Aires: Institución Cultural Argentino-Germana. 
Barrer, F. (1984). Cuerpo y Temblor. Un ensayo sobre la sujeción. Buenos Aires: Per Abbat.

Benjamin, W. (1989). "La obra de arte en la época de su reproductibilidad técnica", en: Benjamín. W., Discursos Interrumpidos I. Buenos Aires: Taurus.

Bilbao, S. (2004). Rememorando a Roberto Lehmann-Nitsche. Buenos Aires: La Colmena.

Bonnet, G. (1986). Ver-Ser visto. Madrid: Fundamentos.

Borges, J. L. (1974). Obras Completas. Buenos Aires: EME-CE.

Burton, A. (2005). "Introduction. Archive Fever, Archive Histories”, en: Burton, A. (Ed), Archive stories: facts, fictions, and the writing of history (pp. 1-24). Durham: Duke University Press.

Cáceres Freyre, J. (1981). Estudio preliminar a la obra Tex-tos eróticos del Río de la Plata de Roberto Lehmann-Nitsche. Buenos Aires: Librería Clásica.

Clifford, J. (1995). “Sobre la autoridad etnográfica”, en: Cliford, J., Dilemas de la Cultura. Barcelona: Gedisa. Crones, G. R. (1998). Historia de los Mapas. México: FCE.

Cunietti-Fernando, A. (1996). “El fotógrafo Samuel Rimathe”, en: 5 Congreso de historia de la Fotografía (pp. 113-120). Buenos Aires.

De Jong, I. (2005). Entre indios e inmigrantes: el pensamiento nacionalista y los precursores del folklore en la antropología argentina del cambio de siglo (XIX y XX). Revista de Indias LXV (234), 405-426

Derrida, J. (1997). Mal de Archivo. Una impresión freudiana. Madrid: Trota.

Didi-Huberman, G. (2007). La invención de la histeria. Charcot y la iconografía fotográfica de la Salpêtrièr. Madrid: Cátedra.

Durkheim, E. y Mauss, M. (1998). “Sobre algunas formas primitivas de clasificación”, en: Durkheim, E., Clasificaciones primitivas y Otros ensayos de Antropología Positiva. Barcelona: Ariel.

Edwards, E. (1992). “Introduction”, en: Edwards, E., Anthropology and photography 1860-1920 (pp. 3-17). New Haven; London, Yale University Press.

Farge, A. (1991). La atracción del archivo. Edicions Alfons el Magnànim. Institució Valenciana d'Estudis i Investigació.

Fricová, Y. (1997). “...E procuri che non mi dimentichino i comuni amici...”, en: Iberoamericana Pragesia. XXXI, 132-160.

Foucault, M. (1981). La arqueología del saber. Buenos Aires: Siglo XXI.

Foucault, M. (1984). Las palabras y las cosas. Barcelona: Planeta-De Agostini.

Galíndez, B. (1968). “Notas a La Conquista del Desierto” en: Espinosa, A., La Conquista del Desierto. Buenos Aires: Freeland.

Giordano, M. (2002). "Las múltiples facetas de Guido Boggiani”, en: Boggiani y el Chaco. Una aventura del Siglo XIX. Buenos Aires: Museo de Arte Hispanoamericano Isaac Fernández Blanco.

Giordano, M. (2004). “De Boggiani a Métraux. Ciencia antropológica y fotografía en el Gran Chaco", en: Revista Chilena de Antropología visual. Universidad Academia de Humanismo

Cristiano, Santiago de Chile. http://www.antropologiavisual.cl/americanistas. htm García M. y Chicote, G. (2008). Voces de tinta. La Plata: Editorial de la Universidad de La Plata. Franco, L. (1967). Los Grandes caciques de la Pampa. Bue-nos Aires: Ediciones del Candil. 
Jay, M. (2003). “Regímenes escópicos de la modernidad”, en: Jay, M., Campos de Fuerza. Barcelona: Paidos.

Jay, M. (2007). Ojos Abatidos. La denigración de la visión en el pensamiento francés del siglo XX. Madrid: Akal.

Leclerc, H. (1986). Ansichten über Ansischtkarten. Archiv für deutche Postgeschichte 2, 5-65.

Lehmann-Nitsche, R. (1899). Quelques observations nouvelles sur les indies Guayaquí du Paraguay. Revista del Museo de la Plata, Tomo IX, 399-408.

Lehmann-Nitsche, R. (1904). Études anthropologiques sur les indiens Takshik du Chaco Argentin. Revista del Museo de la Plata, Tomo XI (Separata).

Lehmann-Nitsche, R. (1908). Estudios antropológicos sobre los chiriguanos, chorotes, matacos y tobas. La Plata: Anales del Museo de la Plata.

Lehmann-Nitsche, R. (1915). Études anthropologiques sur les indiens ona de la Terre de Feu. Revista del Mu-seo de la Plata, Tomo XXIII, 174-184. (separata).

Lehmann-Nitsche, R. (1915a). Relevamiento Antropológico de dos indias alakaluf. Revista del Museo de la Plata, Tomo XXIII, 189-191 (separata).

Lehmann-Nitsche, R. (1915b). Relevamiento Antropológico de una india Yagán. Revista del Museo de la Plata, Tomo XXIII, 185-187 (separata).

Martinez, A. (2011). Imágenes fotográficas sobre pueblos indígenas. Un enfoque antropológico. Tesis Doctoral en Ciencias Naturales. Facultad de Ciencias Naturales y Museo. Universidad Nacional de La Plata.

Martinez, A. y Tamagno, L. (2006). La naturalización de la violencia: Un análisis de fotografías antropométricas de principios del siglo XX. Cuadernos de Antropología Social 24, 93-112.

Masotta, C. (1995). Antropología para ver. Sobre los usos de la imagen en la primera Antropología. Revista Causas y Azares 2.

Masotta, C. (2005). "Representación e iconografía de dos tipos nacionales. El caso de las postales etnográficas en Argentina a fines del siglo XIX y principios del XX”, en: Arte y Antropología en la Argentina. Buenos Aires: Espigas

Masotta, C. (2008). Una investigación sobre postales de indios en la Argentina. Hoja de ruta. Revista Alambre. Comunicación, Información, Cultura 1. http://www.re-vistaalambre.com/1.html Masotta, C. (2009). Álbum Postal. Buenos Aires: La Marca.

Nochlin, L. (1991). The Politics of Vision. Essays on Nineteenth-Century Art and Society. London: Thames and Hudson.Olascoaga, M. (1974). Estudio Topográfico de la Pampa y Río Negro. Buenos Aires: Eudeba.

Penhos, M. (1995). “La fotografía del siglo XIX y la construcción de una imagen pública de los indios", en: AAVV, El arte entre lo público y lo privado (pp. 79-89), Buenos Aires: CAIA.

Penhos, M. (2005). “Frente y Perfil. Una indagación acerca de la fotografía en las prácticas antropológicas y criminológicas en Argentina a fines del siglo XIX y principios del XX”, en: AAVV, Arte y Antropología en la Argentina. Buenos Aires: FIAR- Fundación Espigas.

Pinney, C. (1992). "The parallel histories of Anthropology and Photography", en: Edwards, E., Anthropology and photography 1860-1920 (pp. 74-95). New Haven; London: Yale University Press.

Perazzi, P. (2009). Cartografías corporales: las pesquisas antropológicas del doctor Roberto Lehmann-Nitsche. Buenos Aires: 1897-1908. Cuadernos de Antropología Social 29, 121-134. 
Poole, D. (2000). Visión, Raza y Modernidad. Una economía visual del mundo andino de imágenes. Lima: Sur Casa de Estudios del Socialismo.

Pratt, M. L. (1997). Ojos Imperiales. Literatura de viajes y transculturación. Bernal: Universidad de Quilmes.

Prieto, A. (1988). El discurso criollista en la formación de la Argentina moderna. Buenos Aires: Sudamericana.

Sekula, A. (2003). “El cuerpo y el archivo”, en: Calvo, P., Ribalta Delgado, G. y Ribalta Delgado, J. (Comps), Indiferencia y singularidad. Barcelona: Gustavo Gili.Steedman, C. (2001). Dust. The archive and cultural history. New Jersey: Rutgers University Press.Spieker, S. (2008). The big Archive. Art from bureaucracy. Massachusetts: MIT Press.

Stoler, A. L. (2009). Along the archival grain. Epistemic anxieties and colonial common sense. Princeton University Press.

Wallerstein, I. y Balibar, E. (1991). Raza, clase y nación. Madrid: IEPALA.

Yujnovsky, I. (2010). Viajeros a la sombra de Darwin en los confines del siglo XIX argentino. Tesis Doctoral. Centro de Estudios Históricos. Colegio de México.

\section{NOTES}

1. "Almas robadas. Postales de indios" se expuso en el Instituto Nacional de Antropología y Pensamiento Latinoamericano entre setiembre y noviembre de 2010. Contó con el apoyo del Fondo Nacional de las Artes y del Instituto Ibero-Americano de Berlín. Actualmente es una muestra itinerante del INAPL. En mayo de 2011 se montó en el Centro Municipal de Cultura de la Ciudad de Santa Rosa (La Pampa). El proyecto fue presentado junto a la Lic. María José Fernández y a María Julia Cardinal del Museo del Hombre del INAPL, especialistas en museografía y quienes se encargaron del montaje y la preservación de las fotos que fueron exhibidas. Para el tratamiento de las imágenes digitalizadas y ampliadas contamos con la asistencia del fotógrafo Pablo Garber.

2. Algunos pasos de esa investigación sobre postales de indios puede consultarse en Masotta (2008).

3. Como he desarrollado en un trabajo anterior, esa iconografía se fundamentó en un contrapunto semántico entre gauchos e indios. Masculino/femenino, activo/pasivo, cultura/ naturaleza fueron algunos de los tópicos centrales de ese sistema de alteridad entre esas postales (Masotta 2005). Para los vínculos de Lehmann-Nitsche con el criollismo pueden consultarse Prieto (1988), Bilbao (2004) De Jong (2005) y García y Chicote (2008).

4. El concepto "pulsión escópica" (Schaulust), pulsión o goce de ver, proviene del psicoanálisis y permite recorrer los vínculos entre la mirada y el deseo. Aborda a la mirada como un registro particularmente activo en la configuración del mundo y de sí mismo que elabora el sujeto. Fue originalmente considerada por Freud y luego reelaborada por Lacan en torno al estadio del espejo (Bonnet 1985). Su aplicación a los estudios de la imagen desplaza la atención sobre ésta hacia las prácticas, agencias y poderes en función de los cuales operarían como factores conscientes e in-conscientes. Asimismo, y más allá de los usos originales, la "pulsión escópica" es inscripta socialmente en relación a regímenes de visión históricamente establecidos (Jay 2003, 2007).

5. Algunos trabajos sobre la biografía y desempeño de Lehmann-Nitsche son Arenas (1989-90, 1991); Bilbao (2004); De Jong (2005); García y Chicote (2008); Perazzi (2009). 
6. “...dentro de la pintura no hay ningún ojo que vea el cuerpo. La mirada científica, la perspectiva de la filosofía natural, tal vez estén organizadas alrededor del cadáver, pero con el propósito de no verlo. Resulta fácil seguir las líneas de visión. Regresan de los cirujanos hacia nosotros que miramos (cuán reales somos), o se dirigen al Atlas de Anatomía abierto al pie del cadáver. [...] el que ni siquiera vean la carne, pese a la tentadora proximidad que hay entre estas y sus líneas de visión, solo subraya aún más la extraordinaria contorsión histórica por medio de la cual este cuerpo en exhibición se ha vuelto, en un importante sentido, invisible." (Barrer 1984:99-100).

7. La investigación de Bilbao ha descartado la filiación de Lehmann-Nitsche con el nazismo (Bilbao 2004), otras fuentes afirman incluso que fue renuente a presiones que ese régimen ejerciera sobre su trabajo en los últimos años de su vida (Cáceres Freyre 1981).

\section{ABSTRACTS}

The paper describes alternatives and questions of the research about the postcards of Indians made in Argentina (1900-1940). These postcards were displayed at and were the basis for the exhibition "Almas Robadas. Postales de Indios" ["Stolen Souls - Postcards of Indians"], held at the National Institute of Anthropology and Latin American Thought (Instituto Nacional de Antropología y Pensamiento Latinoamericano) in 2010. Then, some of the images participating in the exhibition are presented through their "archive stories". From them, we suggest an approach that may focus on the content of those documents as well as on the biography that establishes them as such (their production, usage, spreading, custody).

Firstly, there is a description of a story in the "1922 National Folklore Survey" on the relationship of photography with the robbery of souls with which the exhibition's general assumptions were identified. Secondly, there are different comments about the chief Pincén's photograph (1878), made public as a postcard. Finally, there is a description of the ethnographic postcards produced by the anthropologist Lehmann-Nitsche, offering an explanation of the case through a reflection on the "atlas", as a device adopted in the 19th century to put the race on view.

El artículo describe alternativas e interrogantes de la investigación sobre postales de indios en la Argentina (1900-1940) en la que se fundamentó la exposición "Almas Robadas. Postales de Indios" realizada en el Instituto Nacional de Antropología y Pensamiento Latinoamericano en 2010. Luego, se presentan algunas de las imágenes que participaron de la muestra a través de sus "Historias de archivo". Con ellas, se sugiere un abordaje que atienda tanto al contenido de esos documentos como a la biografía que las instituye como tales (su producción, usos, circulación, guarda).

En primer lugar se describe un relato de la "Encuesta nacional de Folklore de 1922" sobre la relación de la fotografía con el robo del alma, con el que se caracterizaron los presupuestos generales de la exposición. En segundo lugar, se realizan diferentes comentarios en torno a la foto del cacique Pincén (1878) que fue difundida como postal. Por último, se describen las postales etnográficas producidas por el antropólogo Lehmann-Nitsche proponiendo una explicación del caso por medio de una reflexión sobre el "atlas", como dispositivo, adoptado en el siglo XIX, para hacer ver la raza. 
INDEX

Keywords: Archive, atlas, photography, Lehmann-Nitsche, Argentina, racism.

Palabras claves: archivo, atlas, fotografía, Lehmann-Nitsche, Pincén, racismo.

\section{AUTHOR}

CARLOS MASOTTA

CONICET-UBA-INAPL

Correo electrónico: cmasott@hotmail.com 